\title{
Cytotoxic Acetogenins from the Roots of Annona purpurea
}

\author{
Gustavo Alejandro Hernández-Fuentes ${ }^{1}$, Aída Nelly García-Argáez ${ }^{2,3}$, \\ Ana Lilia Peraza Campos ${ }^{1}$, Iván Delgado-Enciso ${ }^{4}{ }^{\circ}$, Roberto Muñiz-Valencia ${ }^{1}{ }^{\mathbb{C}}$, \\ Francisco Javier Martínez-Martínez ${ }^{1}$, Antonio Toninello ${ }^{5}$, Zeferino Gómez-Sandoval ${ }^{1}{ }^{\mathbb{D}}$,

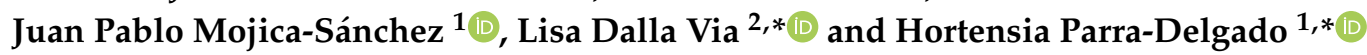 \\ 1 Facultad de Ciencias Químicas, Universidad de Colima, Carretera Colima-Coquimatlán km 9, \\ 28400 Coquimatlán, Colima, Mexico; gahfuentes@gmail.com (G.A.H.-F.); peraza@ucol.mx (A.L.P.C.); \\ robemuva@yahoo.com (R.M.-V.); fjmartin@ucol.mx (F.J.M.-M.); zgomez@ucol.mx (Z.G.-S.); \\ mojica_sanchez@ucol.mx (J.P.M.-S.) \\ 2 Dipartimento di Scienze del Farmaco, Università degli Studi di Padova, Via F. Marzolo 5, 35131 Padova, \\ Italy; aida_nellyg@hotmail.com \\ 3 Fondazione per la Biologia e la Medicina della Rigenerazione T.E.S.-Tissue Engineering and Signalling \\ Onlus, Via F. Marzolo, 13, 35131 Padova, Italy \\ 4 Facultad de Medicina, Universidad de Colima, Av. Universidad 333, Las Víboras, 28040 Colima, Mexico; \\ ivan_delgado_enciso@ucol.mx \\ 5 Dipartimento di Scienze Biomediche, Università degli Studi di Padova, Via G. Colombo 3, 35121, Padova, \\ Italy; antonio.toninello@unipd.it \\ * Correspondence: lisa.dallavia@unipd.it (L.D.V.); hparra@ucol.mx (H.P.-D.); Tel.: +39-(049)-8275712 (L.D.V.); \\ +52-(312)-3161163 (H.P.-D.); Fax: +39-(049)-8275366 (L.D.V.); +52-(312)-3161163 (H.P.-D.)
}

Received: 23 March 2019; Accepted: 6 April 2019; Published: 16 April 2019

\begin{abstract}
Annona purpurea, known in Mexico as "cabeza de negro" or "ilama", belongs to the Annonaceae family. Its roots are employed in folk medicine in several regions of Mexico. Taking that information into account, a chemical and biological analysis of the components present in the roots of this species was proposed. Our results demonstrated that the dichloromethane (DCM) extract was exclusively constituted by a mixture of five new acetogenins named annopurpuricins A-E (1-5). These compounds have an aliphatic chain of 37 carbons with a terminal $\alpha, \beta$ unsaturated $\gamma$-lactone. Compounds 1 and 2 belong to the adjacent bis-THF (tetrahydrofuran) $\alpha$-monohydroxylated type, while compounds 3 and 4 belong to the adjacent bis-THF $\alpha, \alpha^{\prime}$-dihydroxylated type; only compound 5 possesses a bis-epoxide system. Complete structure analysis was carried out by spectroscopy and chemical methods. All compounds were evaluated for their antiproliferative activity on three human tumor cell lines (MSTO-211H, HeLa and HepG2). Compounds 1-4 inhibited significantly the growth of HeLa and HepG2 cells, showing $\mathrm{GI}_{50}$ values in the low/subnanomolar range, while 5 was completely ineffective under the tested conditions. The investigation of the mechanism of action responsible for cytotoxicity revealed for the most interesting compound $\mathbf{1}$ the ability to block the complex I activity on isolated rat liver mitochondria (RLM).
\end{abstract}

Keywords: Annona purpurea; Annonaceae; acetogenins; annopurpuricins; cytotoxicity; mitochondria

\section{Introduction}

The family of Annonaceae is widely distributed in tropical areas. In Mexico, 13 genera and 37 species have been reported. Several species of this family have been used in traditional medicine in many countries and they are characterized by the production of alkaloids, terpenes and acetogenins [1-9]. The annonaceous acetogenins are naturally occurring metabolites that possess long-chain aliphatic backbone 
unique structures. The general structure of acetogenins comprises of a terminal $\alpha, \beta$-unsaturated $\gamma$-lactone and different substituents such as epoxide or tetrahydrofuran (THF) rings along the aliphatic chain [7]. In the acetogenins, these five or six member rings are commonly flanked by hydroxyls, and the presence of double bonds or ketones can be observed [8].

With respect to the biological activities of acetogenins, a wide spectrum of effects has been described, including cytotoxicity on cancer cells and anti-inflammatory activities [10-12]. The biological effects of acetogenins are commonly related to their ability to inhibit NADH: ubiquinone oxidoreductase (complex I) of mitochondrial respiratory chain [7], although other mechanisms of action could participate to the overall biological activity [8]. With respect to the interaction between acetogenins and mitochondrial complex I, several studies have been performed by using both natural and synthetic acetogenins, leading to some structure-activity relationships [13-15].

Annona purpurea Moc \& Sessé ex Dunal is a tree reaching 5-10 m, known in Mexico as "cabeza de negro", "toreta" or "ilama". Several parts of this species are traditionally used in Mexico in folk medicine. In particular, its bark is used for the treatment of dysentery and edema, and the roots are employed against kidney diseases. Moreover, seeds and leaves have been used to prepare insecticide solutions $[5,6]$.

Previous studies of $A$. purpurea described the isolation of bioactive alkaloids and acetogenins [16-20]. From its leaves, acetogenins like rolliniastatin I, bullatacin, purpureacin, cherimoline and sylvaticin have been identified [16]. Likewise, from seeds purpurediolin, purpurenin, annoglaucin, bullatacin, squamocin (annonin I), motrilin (squamocin C), xylomatenin, annonacin A and purpuracenin have been isolated $[19,20]$. In addition, aporphine and oxoaporphine alkaloids have been frequently reported in stems and leaves $[17,18]$. To date, to our knowledge only one study has explored the bioactive components of roots of A. purpurea [21]. In this study, only annomontine $(0.003 \%$ yield $)$, a pyrimidine- $\beta$-carboline alkaloid, with anxiolytic effects, was characterized from a total alkaloid extract. Considering the very little chemical and biological information available on $A$. purpurea roots, the purpose of this work was to determine the main components of the roots, as well as their biological effects, against several cancer cells. In detail, the isolation, structure and absolute configuration of five new acetogenins, exclusive components of the DCM (dichloromethane) extract of the roots of $A$. purpurea, are reported. The new acetogenins isolated in the present study were named as annopurpuricin A (1), annopurpuricin B (2), annopurpuricin C (3), annopurpuricin D (4) and annopurpuricin E (5).

The antiproliferative effect of 1-5 was evaluated on three human tumor cell lines: biphasic mesothelioma (MSTO-211H), cervix adenocarcinoma (HeLa) and hepatocellular carcinoma (HepG2). Moreover, the effect of the most interesting annopurpuricin A (1) on the bioenergetic parameters of isolated RLM was investigated. Finally, the occurrence of mitochondrial membrane depolarization and apoptosis on whole cells were analyzed by cytofluorimetric studies.

\section{Results and Discussion}

\subsection{Isolation and Structure Elucidation}

The DCM extract of the roots of A. purpurea was fractionated by a chromatography column, employing silica gel $60 \AA$ as the stationary phase to give fractions of substituted lactones. Subsequently, the separation by precipitation with different solvent systems afforded pure compounds $\mathbf{1 - 5}$.

A close examination of all compounds showed a similar profile in the spectroscopic data (infrared (IR), ultraviolet-visible spectrophotometry (UV), circular dichroism (CD) and nuclear magnetic resonance [NMR $\left({ }^{1} \mathrm{H}\right.$ and $\left.\left.\left.{ }^{13} \mathrm{C}\right)\right]\right)$. IR spectra contained absorptions for hydroxyl $\left(3369 \mathrm{~cm}^{-1}\right)$ and $\alpha$, $\beta$-unsaturated lactone $\left(1737-1748 \mathrm{~cm}^{-1}\right)$ functionalities. UV $\lambda$ max absorptions were observed between 208-212 nm [methanol (MeOH)]. The positive Kedde reaction as well as the comparison of ${ }^{1} \mathrm{H}$ and ${ }^{13} \mathrm{C}$ NMR data of the isolated (1-5) with those reported for known acetogenins, made evident the presence of the terminal $\alpha, \beta$-unsaturated $\gamma$-lactone (Tables 1 and 2) [22]. Compounds 1-4 showed four signals 
in the ${ }^{13} \mathrm{C}$ NMR spectra corresponding to the THF oxymethines. They were located between $\delta 82.1$ and $83.3 \mathrm{ppm}$ (parts per million) and correlated with the signals at 3.78 to $9.93 \mathrm{ppm}$ in the ${ }^{1} \mathrm{H}$ NMR spectra. A careful analysis of the TMSi (trimethylsilyl) derivatives and the mass spectra revealed that 1-4 had a bis-THF ring system. Unlike the others, the correlations observed in HSQC (heteronuclear single-quantum correlation), COSY (correlated spectroscopy) and HMBC (heteronuclear multiple bond correlation) experiments confirmed that 5 instead of THF units possess an epoxide system with an olefinic bond separated by two methylenes.

Table 1. ${ }^{1} \mathrm{H}$ and ${ }^{13} \mathrm{C}$ NMR data for compounds 1 and 2 recorded in $\mathrm{CDCl}_{3}{ }^{\mathrm{a}}$.

\begin{tabular}{|c|c|c|c|c|}
\hline \multirow[b]{2}{*}{ Position } & \multicolumn{2}{|l|}{1} & \multicolumn{2}{|c|}{2} \\
\hline & $\delta_{\mathrm{H}}(J \mathrm{~Hz})$ & $\delta_{C}$ & $\delta_{\mathrm{H}}(J \mathbf{H z})$ & $\delta_{C}$ \\
\hline 1 & - & $174.0 \mathrm{C}$ & - & $174.7 \mathrm{C}$ \\
\hline 2 & - & $134.4 \mathrm{C}$ & - & $131.3 \mathrm{C}$ \\
\hline $3 a$ & $2.24 \mathrm{br} \mathrm{t}$ & $25.1 \mathrm{CH}_{2}$ & $2.38 \mathrm{~m}$ & $33.4 \mathrm{CH}_{2}$ \\
\hline $3 b$ & $2.24 \mathrm{br} \mathrm{t}$ & $25.1 \mathrm{CH}_{2}$ & $2.51 \mathrm{~m}$ & $33.4 \mathrm{CH}_{2}$ \\
\hline 4 & $1.51 \mathrm{~m}$ & $25.3 \mathrm{CH}_{2}$ & $3.81 \mathrm{~m}$ & $70.0 \mathrm{CH}$ \\
\hline 5 & $1.29 \mathrm{~m}$ & $29.4 \mathrm{CH}_{2}$ & $1.62 \mathrm{~m}$ & $29.6 \mathrm{CH}_{2}$ \\
\hline 6 & $3.82 \mathrm{~m}$ & $71.4 \mathrm{CH}$ & 1.22 br s & $29.6-29.8 \mathrm{CH}_{2}$ \\
\hline 7 & $1.33 \mathrm{~m}$ & $32.0 \mathrm{CH}_{2}$ & 1.22 br s & $29.6-29.8 \mathrm{CH}_{2}$ \\
\hline 8 & $1.23 \mathrm{br} \mathrm{s}$ & $29.5 \mathrm{CH}_{2}$ & 1.22 br s & $29.6-29.8 \mathrm{CH}_{2}$ \\
\hline 9 & 1.23 br s & $29.5 \mathrm{CH}_{2}$ & 1.22 br s & $29.6-29.8 \mathrm{CH}_{2}$ \\
\hline 10 & $1.53 \mathrm{~m}$ & $27.3 \mathrm{CH}_{2}$ & 1.22 br s & $29.6-29.8 \mathrm{CH}_{2}$ \\
\hline 11 & $3.88 \mathrm{~m}$ & $82.5 \mathrm{CH}$ & $1.35 \mathrm{~m}$ & $33.4 \mathrm{CH}_{2}$ \\
\hline 12 & $1.93 \mathrm{~m}$ & $29.0 \mathrm{CH}_{2}$ & $3.37 \mathrm{~m}$ & $74.2 \mathrm{CH}$ \\
\hline 13 & $1.77 \mathrm{~m}$ & $24.6 \mathrm{CH}_{2}$ & $3.79 \mathrm{~m}$ & $83.2 \mathrm{CH}$ \\
\hline 14 & $3.91 \mathrm{~m}$ & $82.7 \mathrm{CH}^{2}$ & $1.93 \mathrm{~m}$ & $29.1 \mathrm{CH}_{2}$ \\
\hline 15 & $3.78 \mathrm{~m}$ & $82.1 \mathrm{CH}$ & $1.56 \mathrm{~m}$ & $28.5 \mathrm{CH}_{2}$ \\
\hline 16 & $1.56 \mathrm{~m}$ & $29.0 \mathrm{CH}_{2}$ & $3.81 \mathrm{~m}$ & $82.2 \mathrm{CH}$ \\
\hline 17 & $1.94 \mathrm{~m}$ & $28.5 \mathrm{CH}_{2}$ & $3.91 \mathrm{~m}$ & $82.8 \mathrm{CH}$ \\
\hline 18 & $3.79 \mathrm{~m}$ & $83.2 \mathrm{CH}$ & $1.81 \mathrm{~m}$ & $24.6 \mathrm{CH}_{2}$ \\
\hline 19 & $3.38 \mathrm{~m}$ & $74.1 \mathrm{CH}$ & $1.97 \mathrm{~m}$ & $29.0 \mathrm{CH}_{2}$ \\
\hline 20 & $1.35 \mathrm{~m}$ & $33.2 \mathrm{CH}_{2}$ & $3.90 \mathrm{~m}$ & $82.4 \mathrm{CH}$ \\
\hline 21 & $1.23 \mathrm{br} \mathrm{s}$ & $29.5 \mathrm{CH}_{2}$ & $1.59 \mathrm{~m}$ & $29.4 \mathrm{CH}_{2}$ \\
\hline 22 & $1.23 \mathrm{br} \mathrm{s}$ & $29.5 \mathrm{CH}_{2}$ & $1.45 \mathrm{~m}$ & $37.5 \mathrm{CH}_{2}$ \\
\hline 23 & $1.40 \mathrm{~m}$ & $37.3 \mathrm{CH}_{2}$ & $3.84 \mathrm{~m}$ & $71.5 \mathrm{CH}$ \\
\hline 24 & $3.55 \mathrm{~m}$ & $71.7 \mathrm{CH}$ & $1.32 \mathrm{~m}$ & $32.0 \mathrm{CH}_{2}$ \\
\hline 25 & $1.39 \mathrm{~m}$ & $37.4 \mathrm{CH}_{2}$ & $1.22 \mathrm{br} \mathrm{s}$ & $29.6-29.8 \mathrm{CH}_{2}$ \\
\hline 26 & $1.23 \mathrm{br} \mathrm{s}$ & $25.1-29.2 \mathrm{CH}_{2}$ & $1.22 \mathrm{br} \mathrm{s}$ & $29.6-29.8 \mathrm{CH}_{2}$ \\
\hline 27 & 1.23 br s & $25.1-29.2 \mathrm{CH}_{2}$ & 1.22 br s & $29.6-29.8 \mathrm{CH}_{2}$ \\
\hline 28 & $1.23 \mathrm{br} \mathrm{s}$ & $25.1-29.2 \mathrm{CH}_{2}$ & $1.22 \mathrm{br} \mathrm{s}$ & $29.6-29.8 \mathrm{CH}_{2}$ \\
\hline 29 & $1.23 \mathrm{br} \mathrm{s}$ & $25.1-29.2 \mathrm{CH}_{2}$ & 1.22 br s & $29.6-29.8 \mathrm{CH}_{2}$ \\
\hline 30 & $1.23 \mathrm{br} \mathrm{s}$ & $25.1-29.2 \mathrm{CH}_{2}$ & 1.22 br s & $29.6-29.8 \mathrm{CH}_{2}$ \\
\hline 31 & $1.23 \mathrm{br} \mathrm{s}$ & $25.1-29.2 \mathrm{CH}_{2}$ & 1.22 br s & $29.6-29.8 \mathrm{CH}_{2}$ \\
\hline 32 & $1.26 \mathrm{~m}$ & $22.7 \mathrm{CH}_{2}$ & $1.22 \mathrm{br} \mathrm{s}$ & $29.6-29.8 \mathrm{CH}_{2}$ \\
\hline 33 & $1.27 \mathrm{~m}$ & $32.0 \mathrm{CH}_{2}$ & $1.28 \mathrm{~m}$ & $32.5 \mathrm{CH}_{2}$ \\
\hline 34 & $0.86 \mathrm{t}(6.76)$ & $14.1 \mathrm{CH}_{3}$ & $0.86 \mathrm{t}(6.9)$ & $14.2 \mathrm{CH}_{3}$ \\
\hline 35 & 6.97 br q (1.48) & $149.0 \mathrm{CH}$ & 7.18 br d (1.3) & $151.9 \mathrm{CH}$ \\
\hline 36 & $4.98 \mathrm{dq}(6.53,5.12,6.76)$ & $77.4 \mathrm{CH}$ & $5.05 \mathrm{qq}(5.48,6.8,6.84)$ & $78.0 \mathrm{CH}$ \\
\hline 37 & $1.38 \mathrm{~d}(6.8)$ & $19.2 \mathrm{CH}_{3}$ & $1.42 \mathrm{~d}(6.8)$ & $19.2 \mathrm{CH}_{3}$ \\
\hline
\end{tabular}

a $\delta$ from TMS (ppm). Assignments confirmed by COSY, HMBC and HSQC experiments (supplementary material)

${ }^{1} \mathrm{H}$ NMR $\left[400 \mathrm{MHz}, \mathrm{CDCl}_{3}, J(\mathrm{~Hz})\right]$ and ${ }^{13} \mathrm{C}$ NMR $(100 \mathrm{MHz})$ data for compounds $\mathbf{1}$ and 2 . br (broad signal). 
Table 2. ${ }^{1} \mathrm{H}$ and ${ }^{13} \mathrm{C}$ NMR data for compounds 3-5, recorded in $\mathrm{CDCl}_{3}{ }^{\mathrm{a}}$.

\begin{tabular}{|c|c|c|c|c|c|c|}
\hline \multirow[b]{2}{*}{ Position } & \multicolumn{2}{|l|}{3} & \multicolumn{2}{|l|}{4} & \multicolumn{2}{|l|}{5} \\
\hline & $\delta_{H}(J \mathbf{H z})$ & $\delta_{C}$ & $\delta_{H}(J \mathbf{H z})$ & $\delta_{C}$ & $\delta_{\mathrm{H}}(J \mathbf{H z})$ & $\delta_{C}$ \\
\hline 1 & - & $174.0 \mathrm{C}$ & - & $174.6 \mathrm{C}$ & - & $174.0 \mathrm{C}$ \\
\hline 2 & - & $134.5 \mathrm{C}$ & - & $131.3 \mathrm{C}$ & - & $134.5 \mathrm{C}$ \\
\hline $3 a$ & $2.25 \mathrm{t}$ & $25.3 \mathrm{CH}_{2}$ & $2.37 \mathrm{~m}$ & $33.4 \mathrm{CH}_{2}$ & $2.25 \mathrm{~m}$ & $25.4 \mathrm{CH}_{2}$ \\
\hline $3 b$ & $2.25 \mathrm{t}$ & $25.3 \mathrm{CH}_{2}$ & $2.50 \mathrm{~m}$ & $33.4 \mathrm{CH}_{2}$ & $2.25 \mathrm{~m}$ & $25.4 \mathrm{CH}_{2}$ \\
\hline 4 & $1.51 \mathrm{~m}$ & $27.5 \mathrm{CH}_{2}$ & $3.82 \mathrm{~m}$ & $70.0 \mathrm{CH}$ & $1.52 \mathrm{~m}$ & $26.7 \mathrm{CH}_{2}$ \\
\hline 5 & $1.30 \mathrm{~m}$ & $26.1 \mathrm{CH}_{2}$ & $1.45 \mathrm{~m}$ & $37.5 \mathrm{CH}_{2}$ & $1.32 \mathrm{br} \mathrm{s}$ & $27.4 \mathrm{CH}_{2}$ \\
\hline 6 & 1.24 br s & $\begin{array}{c}29.3-29.8 \\
\mathrm{CH}_{2}\end{array}$ & 1.24 br s & $\begin{array}{c}29.6-29.8 \\
\mathrm{CH}_{2}\end{array}$ & 1.32 br s & $\begin{array}{c}29.7-28.8 \\
\mathrm{CH}_{2}\end{array}$ \\
\hline 7 & $1.24 \mathrm{br} \mathrm{s}$ & $\begin{array}{c}29.3-29.8 \\
\mathrm{CH}_{2}\end{array}$ & $1.24 \mathrm{br} \mathrm{s}$ & $\begin{array}{c}29.6-29.8 \\
\mathrm{CH}_{2}\end{array}$ & $1.32 \mathrm{br} \mathrm{s}$ & $\begin{array}{c}29.7-28.8 \\
\mathrm{CH}_{2}\end{array}$ \\
\hline 8 & $1.24 \mathrm{br} \mathrm{s}$ & $\begin{array}{c}29.3-29.8 \\
\mathrm{CH}_{2}\end{array}$ & $1.24 \mathrm{br} \mathrm{s}$ & $\begin{array}{c}29.6-29.8 \\
\mathrm{CH}_{2}\end{array}$ & $1.32 \mathrm{br} \mathrm{s}$ & $\begin{array}{c}29.7-28.8 \\
\mathrm{CH}_{2}\end{array}$ \\
\hline 9 & $1.34 \mathrm{~m}$ & $32.6 \mathrm{CH}_{2}$ & $1.24 \mathrm{br} \mathrm{s}$ & $\begin{array}{c}29.6-29.8 \\
\mathrm{CH}_{2}\end{array}$ & $1.32 \mathrm{br} \mathrm{s}$ & $\begin{array}{c}29.7-28.8 \\
\mathrm{CH}_{2}\end{array}$ \\
\hline 10 & $3.88 \mathrm{~m}$ & $71.4 \mathrm{CH}$ & $1.45 \mathrm{~m}$ & $25.76 \mathrm{CH}_{2}$ & 1.32 br s & $\begin{array}{c}29.7-28.8 \\
\mathrm{CH}_{2}\end{array}$ \\
\hline 11 & $3.82 \mathrm{~m}$ & $82.2 \mathrm{CH}$ & $1.37 \mathrm{~m}$ & $33.3 \mathrm{CH}_{2}$ & $1.51 \mathrm{~m}$ & $27.9 \mathrm{CH}_{2}$ \\
\hline 12 & $1.94 \mathrm{~m}$ & $29.1 \mathrm{CH}_{2}$ & $3.38 \mathrm{~m}$ & $74.2 \mathrm{CH}$ & $2.97 \mathrm{~m}$ & $57.0 \mathrm{CH}$ \\
\hline 13 & $1.78,1.87 \mathrm{~m}$ & $24.6 \mathrm{CH}_{2}$ & $3.81 \mathrm{~m}$ & $83.3 \mathrm{CH}$ & $2.95 \mathrm{~m}$ & $56.9 \mathrm{CH}$ \\
\hline 14 & $3.92 \mathrm{~m}$ & $82.8 \mathrm{CH}$ & $1.95 \mathrm{~m}$ & $29.0 \mathrm{CH}_{2}$ & $2.95 \mathrm{~m}$ & $56.8 \mathrm{CH}$ \\
\hline 15 & $3.90 \mathrm{~m}$ & $82.5 \mathrm{CH}$ & $1.59 \mathrm{~m}$ & $28.5 \mathrm{CH}_{2}$ & $2.95 \mathrm{~m}$ & $57.4 \mathrm{CH}$ \\
\hline 16 & $1.58,1.95 \mathrm{~m}$ & $29.0 \mathrm{CH}_{2}$ & $3.80 \mathrm{~m}$ & $82.3 \mathrm{CH}$ & $1.59 \mathrm{~m}$ & $28.1 \mathrm{CH}_{2}$ \\
\hline 17 & $1.61 \mathrm{~m}$ & $28.5 \mathrm{CH}_{2}$ & $3.91 \mathrm{~m}$ & $82.6 \mathrm{CH}$ & $2.21 \mathrm{~m}$ & $24.4 \mathrm{CH}_{2}$ \\
\hline 18 & $3.80 \mathrm{~m}$ & $83.3 \mathrm{CH}$ & $1.56,1.96 \mathrm{~m}$ & $29.0 \mathrm{CH}_{2}$ & $5.37 \mathrm{~m}$ & $128.2 \mathrm{CH}$ \\
\hline 19 & $3.39 \mathrm{~m}$ & $74.2 \mathrm{CH}$ & $1.88 \mathrm{~m}$ & $24.6 \mathrm{CH}_{2}$ & $5.40 \mathrm{~m}$ & $131.3 \mathrm{CH}$ \\
\hline 20 & $1.37 \mathrm{~m}$ & $33.5 \mathrm{CH}_{2}$ & $3.93 \mathrm{~m}$ & $82.9 \mathrm{CH}$ & $2.02 \mathrm{~m}$ & $27.5 \mathrm{CH}_{2}$ \\
\hline 21 & 1.24 br s & $\begin{array}{c}29.3-29.8 \\
\mathrm{CH}_{2}\end{array}$ & $3.84 \mathrm{~m}$ & $71.5 \mathrm{CH}$ & $1.32 \mathrm{~m}$ & $29.4 \mathrm{CH}_{2}$ \\
\hline 22 & $1.24 \mathrm{br} \mathrm{s}$ & $\begin{array}{c}29.3-29.8 \\
\mathrm{CH}_{2}\end{array}$ & $1.33 \mathrm{~m}$ & $32.5 \mathrm{CH}_{2}$ & $1.27 \mathrm{br} \mathrm{s}$ & $\begin{array}{c}29.7-28.8 \\
\mathrm{CH}_{2}\end{array}$ \\
\hline 23 & $1.24 \mathrm{br} \mathrm{s}$ & $\begin{array}{c}29.3-29.8 \\
\mathrm{CH}_{2}\end{array}$ & $1.24 \mathrm{br} \mathrm{s}$ & $\begin{array}{c}29.6-29.8 \\
\mathrm{CH}_{2}\end{array}$ & $1.27 \mathrm{br} \mathrm{s}$ & $\begin{array}{c}29.7-28.8 \\
\mathrm{CH}_{2}\end{array}$ \\
\hline 24 & $1.24 \mathrm{br} \mathrm{s}$ & $\begin{array}{c}29.3-29.8 \\
\mathrm{CH}_{2}\end{array}$ & $1.24 \mathrm{br} \mathrm{s}$ & $\begin{array}{c}29.6-29.8 \\
\mathrm{CH}_{2}\end{array}$ & $1.27 \mathrm{br} \mathrm{s}$ & $\begin{array}{c}29.7-28.8 \\
\mathrm{CH}_{2}\end{array}$ \\
\hline 25 & $1.24 \mathrm{br} \mathrm{s}$ & $\begin{array}{l}29.3-29.8 \\
\mathrm{CH}_{2}\end{array}$ & $1.24 \mathrm{br} \mathrm{s}$ & $\begin{array}{c}29.6-29.8 \\
\mathrm{CH}_{2}\end{array}$ & $1.27 \mathrm{br} \mathrm{s}$ & $\begin{array}{c}29.7-28.8 \\
\mathrm{CH}_{2}\end{array}$ \\
\hline 26 & $1.24 \mathrm{br} \mathrm{s}$ & $\begin{array}{c}29.3-29.8 \\
\mathrm{CH}_{2}\end{array}$ & $1.24 \mathrm{br} \mathrm{s}$ & $\begin{array}{c}29.6-29.8 \\
\mathrm{CH}_{2}\end{array}$ & $1.27 \mathrm{br} \mathrm{s}$ & $\begin{array}{c}29.7-28.8 \\
\mathrm{CH}_{2}\end{array}$ \\
\hline 27 & $1.24 \mathrm{br} \mathrm{s}$ & $\begin{array}{c}29.3-29.8 \\
\mathrm{CH}_{2}\end{array}$ & $1.24 \mathrm{br} \mathrm{s}$ & $\begin{array}{c}29.6-29.8 \\
\mathrm{CH}_{2}\end{array}$ & $1.27 \mathrm{br} \mathrm{s}$ & $\begin{array}{c}29.7-28.8 \\
\mathrm{CH}_{2}\end{array}$ \\
\hline 28 & $1.24 \mathrm{br} \mathrm{s}$ & $\begin{array}{c}29.3-29.8 \\
\mathrm{CH}_{2}\end{array}$ & $1.24 \mathrm{br} \mathrm{s}$ & $\begin{array}{c}29.6-29.8 \\
\mathrm{CH}_{2}\end{array}$ & $1.27 \mathrm{br} \mathrm{s}$ & $\begin{array}{c}29.7-28.8 \\
\mathrm{CH}_{2}\end{array}$ \\
\hline 29 & $1.24 \mathrm{br} \mathrm{s}$ & $\begin{array}{c}29.3-29.8 \\
\mathrm{CH}_{2}\end{array}$ & $1.24 \mathrm{br} \mathrm{s}$ & $\begin{array}{c}29.6-29.8 \\
\mathrm{CH}_{2}\end{array}$ & $1.27 \mathrm{br} \mathrm{s}$ & $\begin{array}{c}29.7-28.8 \\
\mathrm{CH}_{2}\end{array}$ \\
\hline 30 & $1.24 \mathrm{br} \mathrm{s}$ & $\begin{array}{c}29.3-29.8 \\
\mathrm{CH}_{2}\end{array}$ & $1.24 \mathrm{br} \mathrm{s}$ & $\begin{array}{c}29.6-29.8 \\
\mathrm{CH}_{2}\end{array}$ & $1.27 \mathrm{br} \mathrm{s}$ & $\begin{array}{c}29.7-28.8 \\
\mathrm{CH}_{2}\end{array}$ \\
\hline 31 & $1.24 \mathrm{br} \mathrm{s}$ & $\begin{array}{c}29.3-29.8 \\
\mathrm{CH}_{2}\end{array}$ & $1.24 \mathrm{br} \mathrm{s}$ & $\begin{array}{c}29.6-29.8 \\
\mathrm{CH}_{2}\end{array}$ & $1.27 \mathrm{br} \mathrm{s}$ & $\begin{array}{c}29.7-28.8 \\
\mathrm{CH}_{2}\end{array}$ \\
\hline 32 & $1.27 \mathrm{~m}$ & $22.8 \mathrm{CH}_{2}$ & $1.24 \mathrm{br} \mathrm{s}$ & $32.0 \mathrm{CH}_{2}$ & $1.24 \mathrm{br} \mathrm{s}$ & $32.0 \mathrm{CH}_{2}$ \\
\hline 33 & $1.26 \mathrm{~m}$ & $32.0 \mathrm{CH}_{2}$ & $1.27 \mathrm{~m}$ & $22.8 \mathrm{CH}_{2}$ & $1.26 \mathrm{~m}$ & $22.8 \mathrm{CH}_{2}$ \\
\hline 34 & $0.86 \mathrm{t}(6.9)$ & $14.2 \mathrm{CH}_{3}$ & $0.85 \mathrm{t}(6.9)$ & $14.2 \mathrm{CH}_{3}$ & $0.87 \mathrm{t}(6.9)$ & $14.2 \mathrm{CH}_{3}$ \\
\hline 35 & $6.98 \mathrm{q}(1.48,1.56,1.52)$ & $148.9 \mathrm{CH}$ & 7.18 br d (1.3) & $151.8 \mathrm{CH}$ & $\begin{array}{c}6.98 \mathrm{q}(1.48,1.56 \\
1.52)\end{array}$ & $148.9 \mathrm{CH}$ \\
\hline 36 & $\begin{array}{c}4.99 \mathrm{qq}(5.08,1.72, \\
5.08)\end{array}$ & $77.4 \mathrm{CH}$ & $\begin{array}{c}5.04 \mathrm{qq}(5.48,6.8 \\
6.84)\end{array}$ & $78.0 \mathrm{CH}$ & $\begin{array}{c}4.99 \mathrm{qq}(5.08,1.72, \\
5.08)\end{array}$ & $77.4 \mathrm{CH}$ \\
\hline 37 & $1.39 \mathrm{~d}(6.8)$ & $19.3 \mathrm{CH}_{3}$ & $1.41 \mathrm{~d}(6.8)$ & $19.2 \mathrm{CH}_{3}$ & $1.40 \mathrm{~d}(6.8)$ & $19.3 \mathrm{CH}_{3}$ \\
\hline
\end{tabular}

a $\delta$ from TMS (ppm). Assignments confirmed by COSY, HMBC and HSQC experiments (supplementary material). ${ }^{1} \mathrm{H}$ NMR $\left[400 \mathrm{MHz}, \mathrm{CDCl}_{3}, J(\mathrm{~Hz})\right]$ and ${ }^{13} \mathrm{C}$ NMR (100 MHz) spectroscopic data for compounds 3, 4 and 5 . br (broad signal).

The absolute configuration of C-36 in annopurpuricins A to E (1-5) were determined according to Gawroński and $\mathrm{Wu}$ [23] by circular dichroism and showed a negative $\mathrm{n}-\pi^{*}$ Cotton effect at $237.5 \mathrm{~nm}$ $(\Delta \varepsilon=-2.0981)$ and a positive $\pi-\pi^{*}$ Cotton effect at $211 \mathrm{~nm}(\Delta \varepsilon=14.7264)$, clearly indicating an $S$ configuration for all compounds.

The presence of a correlation of the proton at 3.81-3.82 ppm (H-4) with the proton at 2.50-2.51 ppm (H-3b) in the COSY experiment as well as a fragment ion at $m / z 213$ (cleavage between C-4/5) 
obtained by the tri-TMSi derivative, confirmed the position of the hydroxyl group at C-4 in 2 and $4[24,25]$.

\subsubsection{Annopurpuricin A (1)}

Compound 1 was obtained as a yellow powder, $\mathrm{mp} 57-60{ }^{\circ} \mathrm{C}$. The molecular formula was established as $\mathrm{C}_{37} \mathrm{H}_{66} \mathrm{O}_{7}$ by high-resolution mass spectra (HRMS) using electrospray ionization time-of-flight mass spectrometry (ESI-TOF). The existence of three hydroxyl moieties in the molecule was demonstrated by the detection of three signals at 2.00-2.04 ppm in the ${ }^{1} \mathrm{H}$ NMR spectrum of its acetate derivate 1a (supplementary material). The three hydroxyl moieties appeared in the ${ }^{1} \mathrm{H}$ NMR spectrum from $\delta 3.38$ to $3.82 \mathrm{ppm}$ and in the ${ }^{13} \mathrm{C}$ NMR at $\delta 71.4$ to $74.1 \mathrm{ppm}$ (Table 1 ). The position of the hydroxyl groups, as well as the bis-THF unit, was located along the aliphatic chain by the analysis of the fragmentation pattern of the natural compound and its derivative (Figure 1, annopurpuricin A). The first hydroxyl group was situated at C-6 taking into consideration the fragment ions at $\mathrm{m} / \mathrm{z}$ 241 (cleavage between C-6/7) and 429 ( $\mathrm{m} / \mathrm{z} 699$ loses three TMSiO molecules). The second hydroxyl group was located flanking the THF system, according to the COSY and HMBC experiments [ $\delta \mathrm{C}$ 74.14 with $\delta \mathrm{H} 3.37(\mathrm{H}, \mathrm{C}-19)$ ]; as well as the fragment ions at $\mathrm{m} / \mathrm{z} 535$ (cleavage at C-19/20) and $\mathrm{m} / \mathrm{z} 401$ (cleavage at C-18/19) in the TMSi mass spectra. The third hydroxyl moiety was placed in C-24 by the presence of the fragment ions at $\mathrm{m} / \mathrm{z} 345$ and 425 , cleavage between C-23/24 and C-24/25 respectively. A COSY experiment using benzene- $d_{6}\left(\mathrm{C}_{6} \mathrm{D}_{6}\right)$ as solvent allowed identifying a THF system with only one flanking hydroxyl moiety $(3.49 / 3.85 \mathrm{ppm})$ (supplementary material). The stereochemistry of the carbinols was determined by employing the methodology of Rieser et al. [26] which includes the generation of the esters of the acid $R$ and $S$ of Mosher (Table 3). Stereochemistry at C-6, C-19 and C-24 were established as $R, R, S$ respectively. The relative stereochemistry around the bis-THF rings was determined as trans/threo/cis/threo by a comparison to the literature with the ${ }^{1} \mathrm{H}$ and ${ }^{13} \mathrm{C}$ NMR data of the compounds rollidecin (C and D), guanaconne and glabracin A [27-29].

Table 3. ${ }^{1} \mathrm{H}$ NMR data of the Mosher esters of $1-4{ }^{\mathrm{a}}$.

\begin{tabular}{|c|c|c|c|c|c|c|c|c|c|c|c|c|}
\hline \multirow[t]{2}{*}{$\begin{array}{l}\text { MTPA } \\
\text { Config. }\end{array}$} & \multicolumn{9}{|c|}{ Proton Chemical Shifts } & \multicolumn{3}{|c|}{$\begin{array}{c}\text { Carbinol } \\
\text { Configuration }\end{array}$} \\
\hline & H (4) & H (5) & H (7) & $\begin{array}{c}\mathrm{H} \\
(10)\end{array}$ & $\begin{array}{c}\mathrm{H} \\
\mathbf{( 1 7 )}\end{array}$ & $\begin{array}{c}\mathrm{H} \\
(\mathbf{1 8})\end{array}$ & $\begin{array}{c}\mathrm{H} \\
(20)\end{array}$ & $\begin{array}{c}\mathrm{H} \\
(23)\end{array}$ & $\begin{array}{c}\mathbf{H} \\
(25)\end{array}$ & \multirow{4}{*}{$6 R$} & \multirow{4}{*}{$19 R$} & \multirow{4}{*}{$24 S$} \\
\hline 1 S-MTPA & 1.52 & 1.33 & 1.61 & 1.15 & 1.38 & 3.38 & 1.63 & 1.99 & 1.80 & & & \\
\hline 1 R-MTPA & 1.56 & 1.35 & 1.57 & 1.13 & 1.39 & 3.39 & 1.59 & 1.97 & 1.85 & & & \\
\hline \multirow[t]{2}{*}{$\Delta \delta_{\mathrm{H}}$} & -0.04 & -0.02 & +0.04 & +0.02 & -0.01 & -0.01 & +0.04 & +0.02 & -0.05 & & & \\
\hline & $\begin{array}{c}\mathrm{H}(3) \\
\mathrm{b}\end{array}$ & $\underset{b}{H(5)}$ & $\begin{array}{c}\mathrm{H} \\
(11)\end{array}$ & $\begin{array}{c}\mathrm{H} \\
(13)\end{array}$ & $\begin{array}{c}\mathrm{H} \\
(16)\end{array}$ & $\begin{array}{c}\mathrm{H} \\
(17)\end{array}$ & $\begin{array}{c}\mathrm{H} \\
(21)\end{array}$ & $\begin{array}{c}\mathrm{H} \\
(24)\end{array}$ & $\begin{array}{c}\mathrm{H} \\
(35)\end{array}$ & \multirow{4}{*}{$4 R$} & \multirow{4}{*}{$12 S$} & \multirow{4}{*}{$23 S$} \\
\hline 2 S-MTPA & 2.58 & 1.61 & 1.41 & 3.91 & 3.82 & 3.39 & 1.92 & 1.62 & 6.73 & & & \\
\hline 2 R-MTPA & 2.64 & 1.59 & 1.61 & 4.05 & 3.76 & 3.37 & 1.58 & 1.63 & 6.98 & & & \\
\hline \multirow[t]{2}{*}{$\Delta \delta_{\mathrm{H}}$} & -0.06 & +0.02 & -0.20 & -0.14 & +0.06 & +0.02 & +0.34 & -0.01 & -0.25 & & & \\
\hline & $\mathrm{H}(4)$ & $\mathrm{H}(9)$ & $\begin{array}{c}\mathrm{H} \\
(11)\end{array}$ & $\begin{array}{c}\mathrm{H} \\
(17)\end{array}$ & $\begin{array}{c}\mathrm{H} \\
(18)\end{array}$ & $\begin{array}{c}\mathrm{H} \\
(20)\end{array}$ & $\begin{array}{c}\mathrm{H} \\
(33)\end{array}$ & $\begin{array}{c}\mathrm{H} \\
(34)\end{array}$ & & \multirow{4}{*}{$10 R$} & \multirow{4}{*}{$19 S$} & \\
\hline 3 S-MTPA & 1.52 & 1.64 & 3.34 & 1.38 & 3.34 & 1.64 & 1.41 & 0.92 & & & & \\
\hline 3 R-MTPA & 1.54 & 1.58 & 3.41 & 1.94 & 3.41 & 1.58 & 1.33 & 0.89 & & & & \\
\hline \multirow[t]{2}{*}{$\Delta \delta_{\mathrm{H}}$} & -0.02 & +0.06 & -0.07 & -0.56 & -0.07 & +0.06 & +0.08 & +0.02 & & & & \\
\hline & $H(3)$ & $\mathrm{H}(5)$ & $\begin{array}{c}\mathrm{H} \\
(11)\end{array}$ & $\begin{array}{c}\mathrm{H} \\
(13)\end{array}$ & $\begin{array}{c}\mathrm{H} \\
(16)\end{array}$ & $\begin{array}{c}\mathrm{H} \\
(17)\end{array}$ & $\begin{array}{c}\mathrm{H} \\
(20)\end{array}$ & $\begin{array}{c}\mathrm{H} \\
(22)\end{array}$ & $\begin{array}{c}\mathrm{H} \\
(35)\end{array}$ & \multirow{4}{*}{$4 R$} & \multirow{4}{*}{$12 R$} & \multirow{4}{*}{$21 S$} \\
\hline 4 S-MTPA & 2.59 & 1.65 & 1.63 & 3.40 & 3.72 & 3.67 & 3.85 & 1.36 & 6.72 & & & \\
\hline 4 R-MTPA & 2.64 & 1.61 & 1.48 & 3.99 & 3.82 & 3.64 & 3.93 & 1.59 & 6.97 & & & \\
\hline$\Delta \delta_{\mathrm{H}}$ & -0.05 & +0.04 & +0.23 & -0.59 & -0.1 & +0.03 & -0.08 & -0.2 & -0.25 & & & \\
\hline
\end{tabular}

${ }^{\mathrm{a}} \mathrm{CDCl}_{3}, 400 \mathrm{MHz}, \Delta \delta_{\mathrm{H}}=\delta \mathrm{S}-\delta \mathrm{R} ;{ }^{\mathrm{b}}$ Independent experiments acquired in $\mathrm{C}_{6} \mathrm{D}_{6}$ were employed only to confirm the configuration at $\mathrm{C}-4\left[\Delta \delta_{\mathrm{H}}: \mathrm{H}-3(-0.01), \mathrm{H}-5(+0.17)\right]$. [30]. 

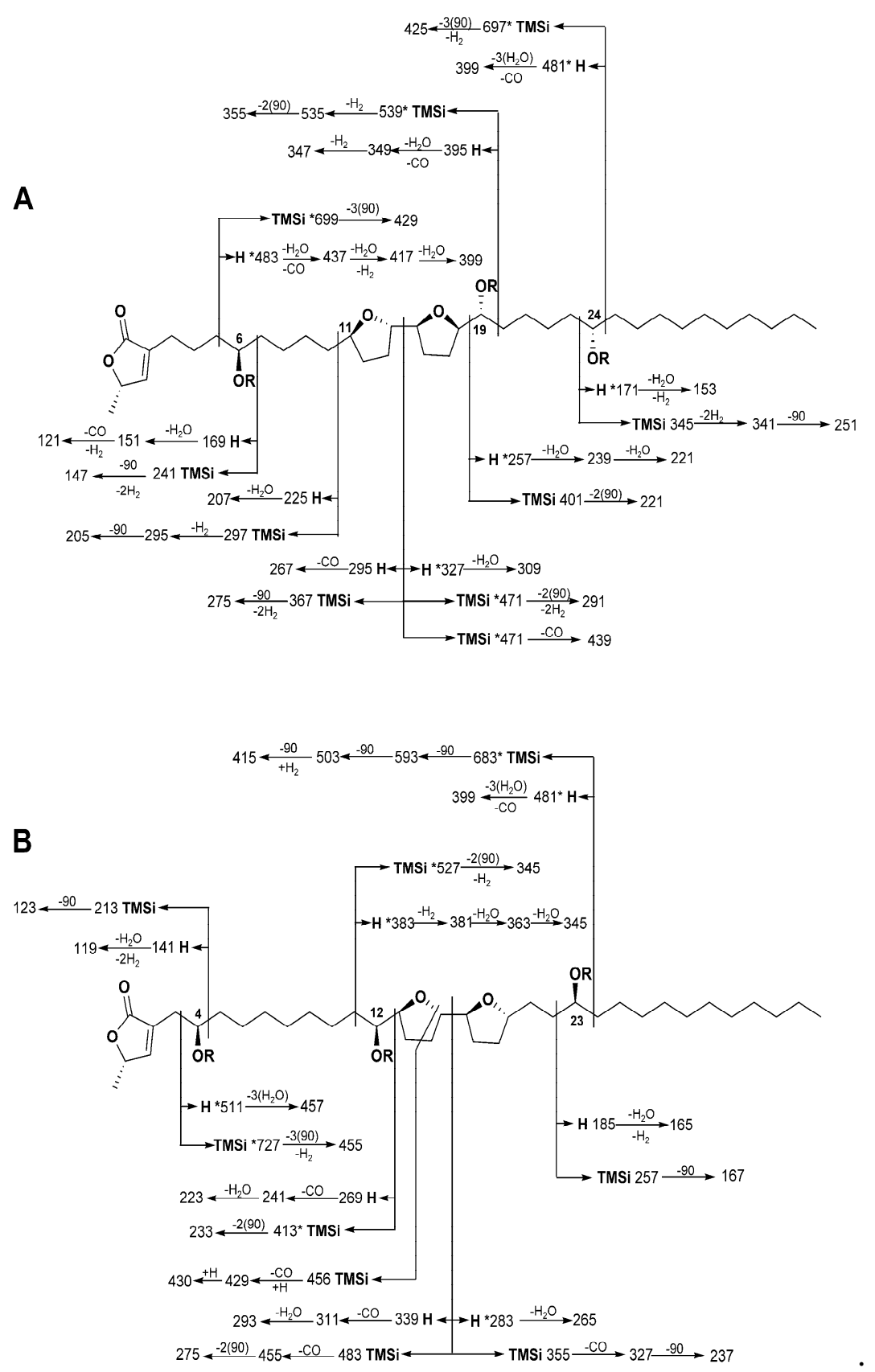

Figure 1. Diagnostic ions in the EI mass spectrum of $\mathbf{1}(\mathbf{A})$ and $\mathbf{2}(\mathbf{B}) \cdot R=\mathrm{H}$ (natural compound) and $R$ $=$ TMSi [trimethylsilyl derivative $\left(m / z\right.$ 90)]. ${ }^{*}$ Peak not observed.

\subsubsection{Annopurpuricin B (2)}

Compound 2 was isolated as a white amorphous powder. Its molecular formula was established as $\mathrm{C}_{37} \mathrm{H}_{66} \mathrm{O}_{7}$ by HRMS (ESI-TOF). The signals corresponding to three hydroxyl moieties appeared in the ${ }^{1} \mathrm{H}$ NMR spectrum from $\delta \mathrm{H} 3.38$ to $3.84 \mathrm{ppm}$ and in the ${ }^{13} \mathrm{C}$ NMR at $\delta 70.0$ to $74.2 \mathrm{ppm}$ (Table 1).

The position of the hydroxyl moieties and the bis-THF unit were located along the aliphatic chain by the analysis of the fragmentation pattern of the TMSi derivate (Figure 1, annopurpuricin B) as well as an analysis at ${ }^{1} \mathrm{H}$ NMR spectra using $\mathrm{C}_{6} \mathrm{D}_{6}$ as solvent (supplementary material). At $\mathrm{C}-12$, a hydroxyl group was placed by the COSY correlation between the protons at $3.37 \mathrm{ppm}(\mathrm{H}-12)$ with $3.79 \mathrm{ppm}$ (H-13). The position of the hydroxyl moiety was supported by fragment ions at $m / z 527$ (cleavage at $C-11 / 12$ ) and $m / z 413$ (cleavage at C-12/13). The third hydroxyl group was placed at C-23 by the fragment ions at $m / z 257$ (cleavage between C-22/23), and $m / z 683$ (cleavage between C-23/24, loses 
three molecules of TMSiO) (Figure 1B) confirmed by the correlation of H-23 with H-22 and H-24 ( $\delta 1.45$ and $1.32 \mathrm{ppm}$ ) that belong to the aliphatic chain.

The carbinol configurations were determined by a similar method as that used with 1 [26]. The analysis of ${ }^{1} \mathrm{H}$ NMR chemical shifts allowed the clear establishment of an $S$ stereochemistry of carbinols at $\mathrm{C}-12$ and $\mathrm{C}-23$. The stereochemistry at $\mathrm{C}-4$ was unequivocally assigned as $R$, taking the following arguments into account. First, considering $\mathrm{H}-35$ and $\mathrm{H}-36$ displacements in $\mathrm{CDCl}_{3}$, the $\Delta \delta(S-R)$ values for $\mathrm{H}-35$ and $\mathrm{H}-36$ were -0.25 and $-0.05 \mathrm{ppm}$, respectively, suggesting an unlike relative configuration for C-4/C-36 therefore, if C-36 has the $S$ configuration, C-4 must have an $R$ configuration [19]. Second, the $\Delta \delta(S-R)$ values for $\mathrm{H}-3$ and $\mathrm{H}-5$ were -0.06 and +0.02 respectively suggesting once again an $R$ stereochemistry. Because of the signal of $\mathrm{H}-5$ in $R$ Mosher's derivative was highly overlapped, additional experiments in $\mathrm{C}_{6} \mathrm{D}_{6}$ were carried out; there, $\Delta \delta(S-R)$ values for $\mathrm{H}-3$ and $\mathrm{H}-5$ were -0.01 and +0.17 respectively, confirming the proposed stereochemistry (Table 3). As observed by Navrátilová et al. [30] in other carbinols, a comparison of calculations $\Delta \delta(S-R)$ values using $\mathrm{C}_{6} \mathrm{D}_{6}$ or $\mathrm{CDCl}_{3}$ can be useful in the study of stereochemistry. The bis-THF rings stereochemistry was assigned by a comparison with the literature indicating that the relative configurations at the bis-THF system from C-12 to C-20 are erythro/trans/threo/trans, similar to guanaconne [27].

\subsubsection{Annopurpuricin C (3)}

Compound 3 was isolated as a white powder, $\mathrm{mp} 69-71^{\circ} \mathrm{C}$. Its molecular formula was established as $\mathrm{C}_{37} \mathrm{H}_{66} \mathrm{O}_{6}$ by HRMS (ESI-TOF). The ${ }^{1} \mathrm{H}$ NMR signals were according to an acetogenin structure (Table 2), as previously discussed, and the presence of two hydroxyls was suggested by the presence of the signals at $\delta 3.39$ and $3.88 \mathrm{ppm}$, and at $\delta 71.4$ and $74.2 \mathrm{ppm}$ in the ${ }^{13} \mathrm{C} \mathrm{NMR}$, which was in agreement with the presence of two signals at $\delta \mathrm{H} 2.05$ and $2.07 \mathrm{ppm}$ in the ${ }^{1} \mathrm{H}$ NMR spectrum of the acetate derivative $3 \mathbf{a}$. A detailed analysis, using $\mathrm{C}_{6} \mathrm{D}_{6}$ as solvent, (supplementary material) was made to prevent overlapping signals and to establish the presence of a bis-THF system with two flanking hydroxyls. In addition, the position of the system was established by the analysis of the fragmentation pattern (Figure 2, annopurpuricin C) were hydroxyl groups were located at C-10 and C-19, and the bis-THF unit at C-11 to C-18. The stereochemistry of the carbinols was determined by employing the same methods for compounds 1 and 2. The NMR chemical shifts of the protons close to C-10 and C-19 in the Mosher derivatives are reported in Table 3; for both carbinols, the configurations were established as $R$ and $S$ respectively [31]. A comparison with the literature of chemical shifts of compound 3 indicated a relative stereochemistry between C-10 to C-19 as erythro/trans/threo/trans/erythro, similar to atemotetrolin and espelicin [24,25,32].

\subsubsection{Annopurpuricin D (4)}

Compound 4 was obtained as a white powder, $\mathrm{mp} 77-78^{\circ} \mathrm{C}$. Its molecular formula was established as $\mathrm{C}_{37} \mathrm{H}_{66} \mathrm{O}_{7}$ by HRMS (ESI-TOF). The analysis of its acetate derivative (4a) allowed the detection of three signals from 2.03 to $2.05 \mathrm{ppm}$ in the ${ }^{1} \mathrm{H}$ NMR spectrum, suggesting the presence of three hydroxyl groups (supplementary material). The position of the hydroxyl groups, as well as the bis-THF unit, were located along the aliphatic chain by the analysis of the fragmentation patterns obtained from the mass spectrometry of the underivatized material and the TMSi derivative (Figure 2, annopurpuricin D). The first hydroxyl group was located at C-4 by the observation of a signal at $70 \mathrm{ppm}$ in the NMR and the correlation between the proton at $3.82 \mathrm{ppm}$ with the signal at $2.50(\mathrm{H}-3 \mathrm{~b})$ in the COSY experiment $[24,25]$. The position in C-4 was confirmed by the fragment ions at $m / z 213$ (cleavage between C-4/5) and $\mathrm{m} / \mathrm{z} 461$ (cleavage between C-3/4). The last two hydroxyl groups were assigned at C-12 and C-21, due to the correlations detected in the COSY and $\mathrm{HMBC}$ experiments employing $\mathrm{CDCl}_{3}$ as solvent. Further, independent experiments using $\mathrm{C}_{6} \mathrm{D}_{6}$ as solvent were carried out. Additional information was obtained by analyzing the mass spectra of the TMSi derivative (Figure 2, annopurpuricin D). The relative configuration of the THF system was established as erythro/trans/threo/trans/erythro, like 
rollitacin [33,34], purpurediolin and purpurenin [20]. Carbinol configurations in 4 were established as C-4R, C-12R, C-21S (Table 3) by the same methods [26].

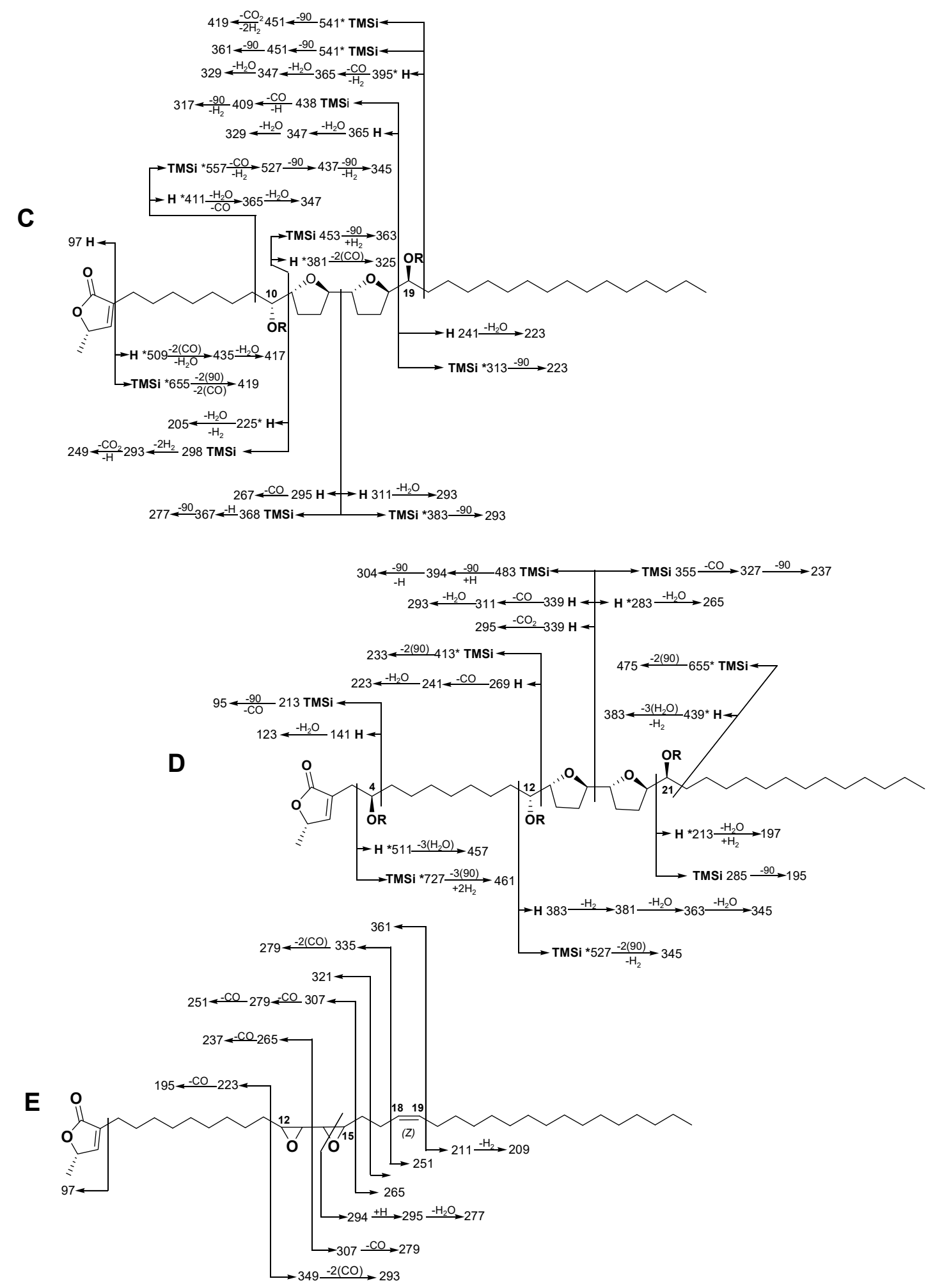

Figure 2. Diagnostic ions in the EI mass spectrum of $\mathbf{3}(\mathrm{C}), \mathbf{4}(\mathrm{D}), \mathbf{5}(\mathrm{E}) . R=\mathrm{H}$ (natural compound) and $R=$ TMSi (trimethylsilyl derivative $(m / z$ 90)). * Peak not observed. 


\subsubsection{Annopurpuricin E (5)}

Compound 5 was isolated as a white powder, $\mathrm{mp} 55-56^{\circ} \mathrm{C}$. Its molecular formula was established as $\mathrm{C}_{37} \mathrm{H}_{64} \mathrm{O}_{4}$ by HRMS (ESI-TOF). The presence of an isolated extra double bond in $\mathbf{5}$ was suggested by a proton multiplet at $\delta 5.39(2 \mathrm{H})$ in the ${ }^{1} \mathrm{H}$ NMR spectrum and two carbon resonances at $\delta 128.2$ and 131.4 in the ${ }^{13} \mathrm{C}$ NMR spectra [33,35-37]. The ${ }^{13} \mathrm{C}$ NMR chemical shifts of the $\alpha$-methylene carbons were $\delta 23.4$ and $\delta 27.2 \mathrm{ppm}$ indicating a $Z$ stereochemistry, (Table 2) [36,37]. The cis configuration of the double bond of 5 was also suggested by a comparison of the chemical displacement with those linear acetogenins reported in the literature [33,35-37]. The position of the double bond at C-18/19 was separated by two methylens from an epoxide system by the fragment ion at $\mathrm{m} / \mathrm{z} 335$ (cleavage of C-17/18) (Figure 2C). This system was confirmed by the correlation between $\delta \mathrm{H} 2.95$ to $2.97 \mathrm{ppm}$ (four protons) and $\delta C 56.9-57.3 \mathrm{ppm}$ [38]. Its position (C12/15) was determined by the fragment ions at $\mathrm{m} / \mathrm{z}$ 307 and 265 (cleavage of C-13/14) (supplementary material).

In addition to the chemical and spectroscopy analysis, a comparison of experimental and calculated vibrational frequencies $\left(\mathrm{cm}^{-1}\right)$ for all annopurpuricins was carried out (see Computational details) [39]. The experimental values were in agreement with those predicted for the proposed structures 1-5 (Tables S13, S26, S39, S52, S62 in supplementary material).

\subsection{Antiproliferative Activity}

The ability of annopurpuricins A-E (1-5) to inhibit cell growth was evaluated by means of an in vitro assay performed on three human tumor cell lines: MSTO-211H (biphasic mesothelioma), HeLa (cervix adenocarcinoma) and HepG2 (liver hepatocellular carcinoma). The results, expressed as $\mathrm{GI}_{50}$ values, i.e., the concentration (nM) of compound able to produce $50 \%$ cell death with respect to the control culture, are shown in Table 4. Camptothecin, a natural product with well-known antiproliferative activity, was used as the reference compound.

Table 4. Cell growth inhibition in the presence of compounds 1-5 and camptothecin taken as reference.

\begin{tabular}{cccc}
\hline \multirow{2}{*}{ Compound } & \multicolumn{3}{c}{ Cell Lines GI $_{\mathbf{5 0}}{ }^{\text {a }}(\mathbf{n M})$} \\
\cline { 2 - 4 } & MSTO-211H & HeLa & HepG2 \\
\hline $\mathbf{1}$ & $25.9 \pm 4.5$ & $0.06 \pm 0.01$ & $0.45 \pm 0.16$ \\
$\mathbf{2}$ & $6.9 \pm 1.9$ & $0.09 \pm 0.02$ & $0.66 \pm 0.09$ \\
$\mathbf{3}$ & $7.2 \pm 1.6$ & $0.41 \pm 0.16$ & $3.0 \pm 1.3$ \\
$\mathbf{4}$ & $7.3 \pm 2.1$ & $0.35 \pm 0.06$ & $2.5 \pm 0.2$ \\
$\mathbf{5}$ & $>50$ & $>50$ & $>50$ \\
Camptothecin & $2.1 \pm 0.1$ * & $5.4 \pm 0.2 *$ & $3.00 \pm 0.20$ \\
\hline * From ref. [40] ${ }^{\text {a }}$ Means values \pm of at least three independent experiments.
\end{tabular}

The obtained results clearly indicate a notable antiproliferative activity for acetogenins $\mathbf{1}-\mathbf{4}$ showing $\mathrm{GI}_{50}$ values ranging from 0.06 to $25.9 \mathrm{nM}$. In particular, annopurpuricin $\mathrm{A}(\mathbf{1})$ is the most active compound on both HeLa and HepG2 cells, being 90 and 6.6 times more potent than camptothecin, respectively. Otherwise, compound $\mathbf{5}$ does not exert any cytotoxicity in the same experimental conditions.

Taking into consideration the acetogenins endowed with antiproliferative activity (1-4), it is possible to note a quite different sensitivity between the different cell lines, with the highest antiproliferative effect on HeLa cells and the lowest on MSTO-211-H. In particular, the GI $\mathrm{I}_{50}$ values obtained for HeLa cells are from about 17 (compound 3) to about 400 (compound 1) times lower with respect to those of MSTO-211H. With respect to Hep-G2, these cells show an intermediate sensitivity with $\mathrm{GI}_{50}$ values ranging from 0.45 to $2.5 \mathrm{nM}$. By considering the most sensitive HeLa and Hep-G2 cell lines, a general behavior can be noted which highlights acetogenin $\mathbf{1}$ as the most active, and $\mathbf{3}$ as the least cytotoxic.

In this connection, taking into consideration the structures depicted in Figures 1 and 2 and the results shown in Table 4, some qualitative structure-activity relationships can be drawn. In particular, 
the lack of cytotoxicity by acetogenin $\mathbf{5}$, could suggest a role for the THF rings, the saturated side chains and the hydroxyl substituents in the biological activity of $\mathbf{1}-\mathbf{4}$. In addition, the relative length of aliphatic chains does not seem determinant for the antiproliferative effect. Indeed, $\mathbf{1}$ and $\mathbf{3}$, as well $\mathbf{2}$ and 4, notwithstanding the significant differences in biological activity, are characterized by the same number of carbon atoms in the aliphatic chains. Similarly, the total number of hydroxyl groups does not appear related with cytotoxicity, because the effect exerted by 3 is not significantly different to those of 4 that possesses, along with two hydroxyl groups flanking the THF rings, a further hydroxyl moiety at C-4 position.

Finally, it has to be underlined that annopurpuricins A-D (1-4) had a relative configuration trans/threo between both THF rings, similar to bullatacin, an acetogenin characterized by notable antiproliferative activity $[10,11]$. Moreover, the molecular model of annopurpuricin A (Figure 3) highlighted structural attributes in agreement with a recent theoretical study which correlates very strong $\mathrm{O}-\mathrm{H}$ stretching intensities, characteristic of hydrogen bonding, with bent $V$-type equilibrium geometry structures [41]. Furthermore, comparisons of the 3D-structures of highly bioactive acetogenins seem to indicate that this special feature could improve the interactions with the target.

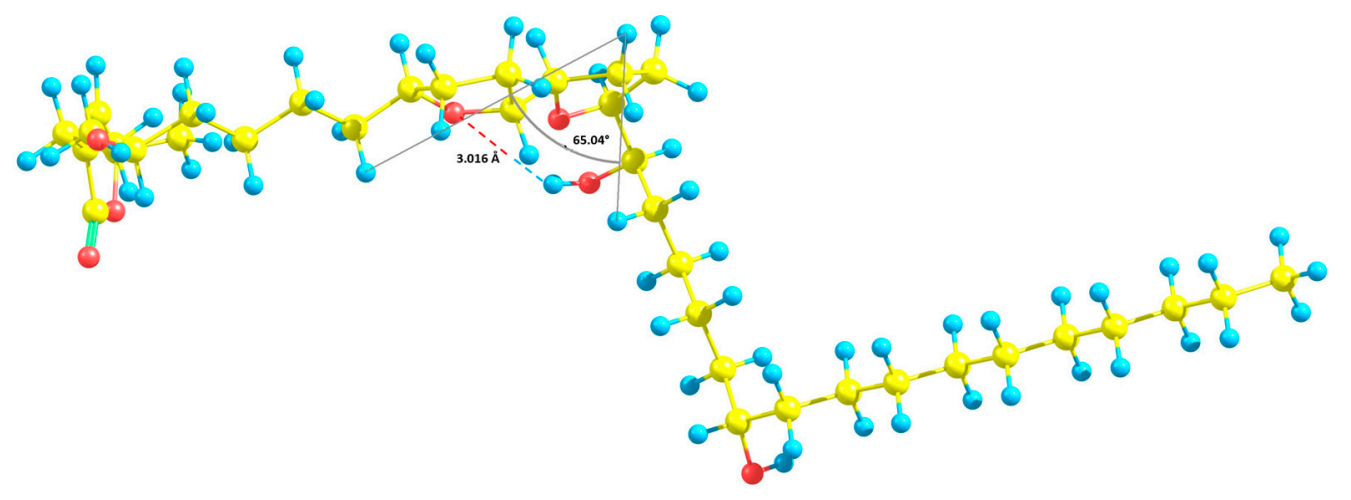

Figure 3. Molecular model of annopurpuricin A (1).

The higher cytotoxic effect of $\mathbf{1}$ with respect to the other isolated acetogenins (2-5) on both HeLa and HepG2 cells prompts us to investigate the mechanism of action responsible for such an interesting biological profile. In particular, on the basis of previous studies demonstrating the ability of acetogenin derivatives to inhibit mitochondrial complex I [13,15], the effect of $\mathbf{1}$ on the bioenergetic parameters in isolated RLM was studied.

\subsection{Effect on Mitochondrial Membrane Potential}

To evaluate the bioenergetic parameters on isolated RLM, the most commonly utilized substrate is succinate (succ) in the presence of rotenone (rot). This is because succ energizes mitochondria by its oxidizing enzyme, succinate dehydrogenase, which is a component of the respiratory chain, the so-called complex II. Rot is an inhibitor of NADH dehydrogenase (complex I), and consequently it inhibits the oxidation of all the NAD-dependent substrates, so emphasizing the oxidation of succ.

In Figure 4A,B a typical bioenergetic experiment showing the mitochondrial membrane potential $(\Delta \Psi)$ establishment by oxidation of succ plus rot is reported, along with the effect of compound 1 . As it is observable in Figure 4A, RLM incubated in a standard medium and energized as above mentioned, exhibit a $\Delta \Psi$ of about $170 \mathrm{mV}$ that is maintained for a long time (dotted line). The addition of antimycin A (ant A), an inhibitor of complex III, rapidly collapses $\Delta \Psi$, while a subsequent addition of ascorbate (asc) plus the shuttle tetramethyl- $p$-phenylendiamine (TMPD), that transfers electrons to cytochrome $C$, restores it. These results demonstrate in the isolated RLM the optimal functioning of the segment of the respiratory chain from complex II to oxygen. 
A

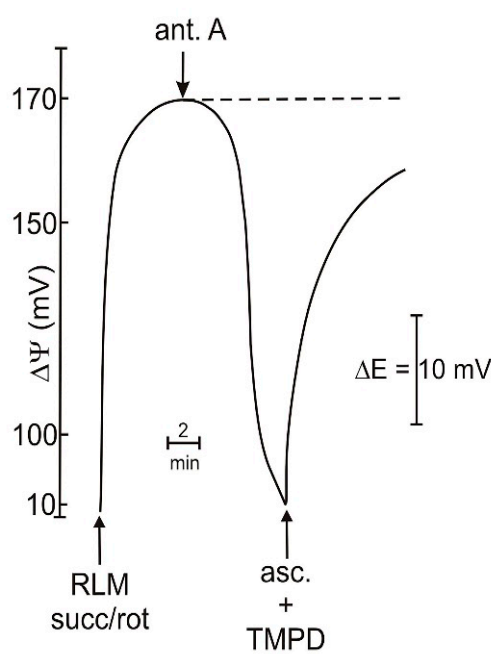

B

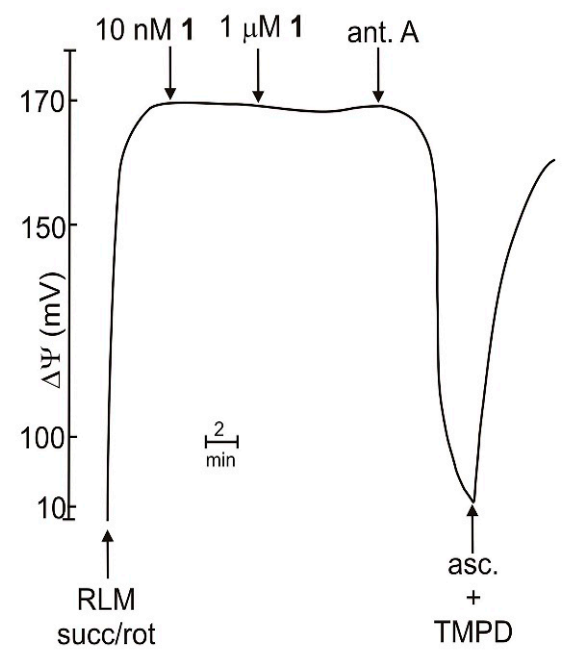

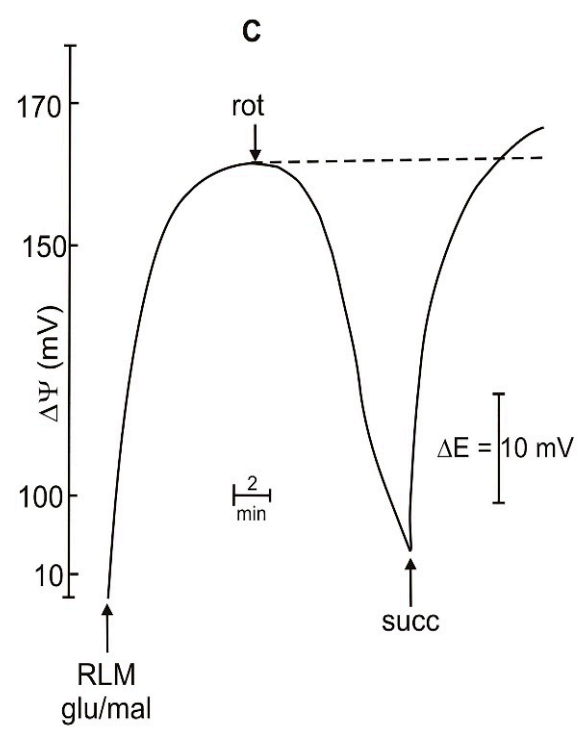

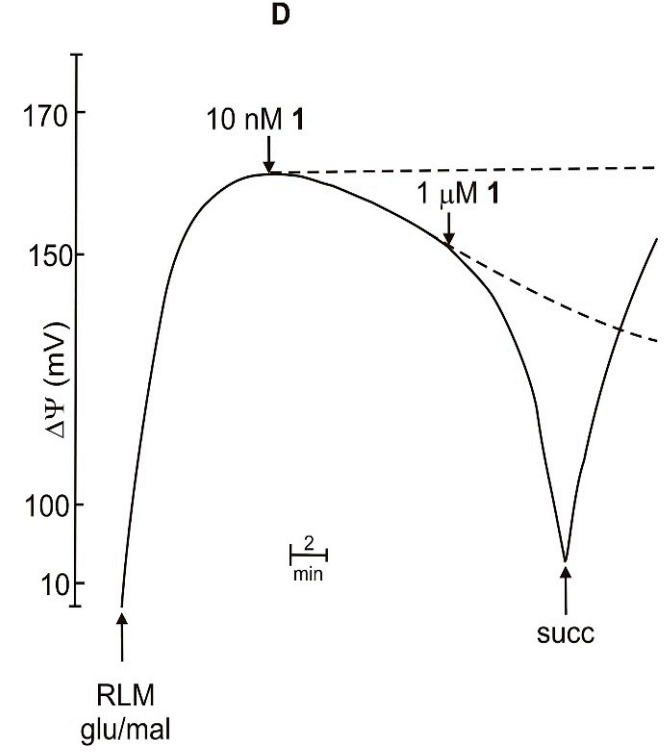

Figure 4. Effects of compound 1 on mitochondrial $\Delta \Psi$. (A,B): RLM $(1 \mathrm{mg} / \mathrm{mL})$ are incubated in a medium containing succ $(5 \mathrm{mM})$ and $\operatorname{rot}(1.25 \mu \mathrm{M})$. $(\mathbf{C}, \mathbf{D})$ : RLM $(1 \mathrm{mg} / \mathrm{mL})$ are incubated in a medium containing glu $(5 \mathrm{mM})$ and $\mathrm{mal}(1 \mathrm{mM})$. Test compound was added at indicated concentrations. When present $10 \mathrm{mM}$ asc, $100 \mu \mathrm{M}$ TMPD, $1.25 \mu \mathrm{M}$ rot, $1 \mu \mathrm{M}$ ant A. Dotted lines represent the behavior of mitochondrial $\Delta \Psi$ without the addition indicated by the arrow.

Annopurpuricin A (1) is ineffective in inducing any change in $\Delta \Psi$ at $10 \mathrm{nM}$ concentration and after a further addition of $1 \mu \mathrm{M}$ (Figure 4B). Addition of ant A, followed by asc/TMPD, exhibits the same effects as in Figure 4A, thus demonstrating that 1 does not alter the membrane integrity and the activity of the proton pumps, and electron transport located on the respiratory chain, downstream complex II.

Figure 4C shows the $\Delta \Psi$ obtained in the presence of glutamate (glu)/malate (mal) as energizing substrates, that is a more physiological condition with respect to that in Figure 4A,B. Glu is transported in mitochondria by the activity of the shuttle malate/aspartate, then it is oxidized to $\alpha$-ketoglutarate by glutamate dehydrogenase with the formation of NADH. The latter transfers electrons to NADH dehydrogenase, the complex I of the respiratory chain. This more complicated pathway causes a slower respiration and a consequent lowering in $\Delta \Psi$. Actually, mitochondrial $\Delta \Psi$ established by the oxidation 
of glu/mal exhibits a value of about $160 \mathrm{mV}$ (Figure 4C, dotted line). As expected, the addition of rot, an inhibitor of NADH dehydrogenase, induces a drop in $\Delta \Psi$, while a subsequent addition of succ restores it at the maximum value (Figure $4 \mathrm{C}$, continuous line). The addition of $10 \mathrm{nM}, \mathbf{1}$ induces a gradual drop in $\Delta \Psi$, which becomes almost completely collapsed at $1 \mu \mathrm{M}$ concentration (Figure $4 \mathrm{D}$, continuous line). A subsequent addition of succ is able to restore $\Delta \Psi$. Overall, the results reported in Figure $4 \mathrm{C}, \mathrm{D}$ suggest for $\mathbf{1}$ a rotenone-like effect.

\subsection{Mitochondrial Respiration Parameters}

Other bioenergetic parameters that characterize mitochondrial functions, and also demonstrate the coupling of mitochondrial respiration with oxidative phosphorylation, are the respiratory control index (RCI) and the ADP (adenosine diphosphate)/O ratio. The results presented in Figure 5A show the calculation of these parameters in RLM energized by succ/rot. As observable in this Figure RCI exhibits a value of about 4 and $\mathrm{ADP} / \mathrm{O}$ ratio of about 1.8, which are values typical of good mitochondrial preparations. The RCI and ADP/O ratio, calculated in the presence of $\mathbf{1}(1 \mu \mathrm{M})$ (Figure 5B), show values of about 3.94 and 1.77, respectively, and this means that the compound exhibits an almost negligible effect on these parameters. If RLM are energized by glu/mal, RCI and ADP/O ratio are about 3.7 and 2.8, respectively (Figure 5C), values in this case typical for these substrates. It is evidenced that both state 4 and state 3 respiration are slightly slower than those observed with succ/rot (compare Figure 5C with Figure 5A), in accordance with the above explanation. The addition of $\mathbf{1}$ at $10 \mathrm{nM}$, at RLM incubated in the presence of glu/mal, inhibited respiration states 4 and 3, with a consequent significant reduction of $\mathrm{RCI}$ and $\mathrm{ADP} / \mathrm{O}$ ratio to 2.5 and 2, respectively (Figure 5D).
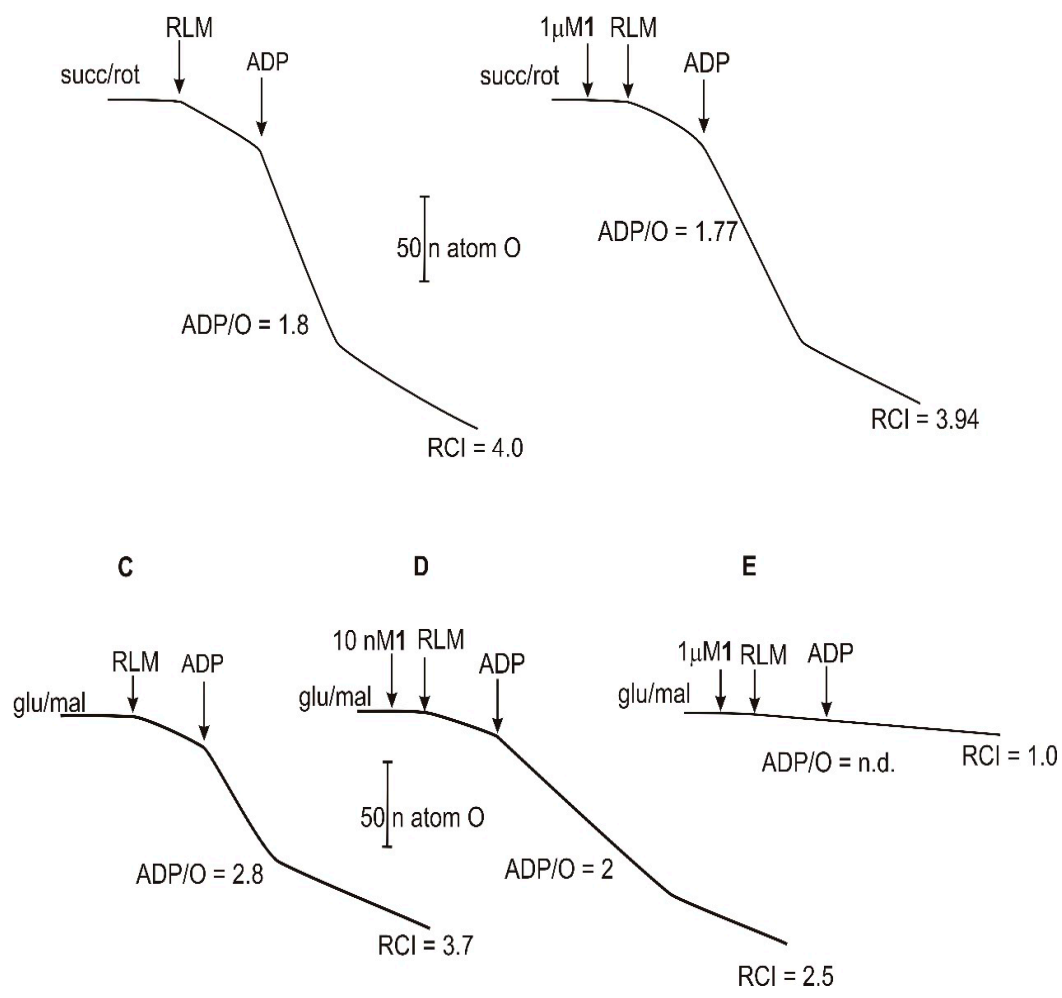

Figure 5. Effects of compound $\mathbf{1}$ on $\mathrm{RCI}$ and ADP/O ratio. (A,B): RLM $(1 \mathrm{mg} / \mathrm{mL})$ were incubated in a medium containing succ $(5 \mathrm{mM})$ and $\operatorname{rot}(1.25 \mu \mathrm{M})$. (C-E): RLM $(1 \mathrm{mg} / \mathrm{mL})$ were incubated in a medium containing glu $(5 \mathrm{mM})$ and $\mathrm{mal}(1 \mathrm{mM})$. Test compound was added at indicated concentrations. ADP concentration was $0.2 \mathrm{mM}$. 
In these experimental conditions, the addition of 1 at $1 \mu \mathrm{M}$ concentration almost completely blocks the oxygen consumption in both the respiratory states, and RCI becomes 1 (the lowest value) while $\mathrm{ADP} / \mathrm{O}$ ratio is not detectable (Figure 5E). These results clearly indicate that $\mathbf{1}$ induces a dose-dependent inhibition of complex I of the respiratory chain, most probably by a rotenone-like effect, in accordance with previous studies on a number of acetogenins and derivatives $[7,13,15]$.

Figure 6 shows the respiration of RLM in state 4 (A) and in uncoupled states induced by carbonylcyanide- $p$-trifluoromethoxyphenylhydrazone (FCCP) (B) in RLM energized with succ/rot. The addition of 1 at $1 \mu \mathrm{M}$ is completely ineffective on oxygen consumption in both cases, by confirming that 1 does not inhibit the electron transport downstream complex I, also at different rates of this transport. Otherwise, with glut/mal (Figure $6 \mathrm{C}, \mathrm{D}$ ), the test compound at $1 \mu \mathrm{M}$ completely blocks oxygen consumption both in state $4(\mathrm{C})$ and in uncoupled state (D), thus confirming the block of complex I activity.

A

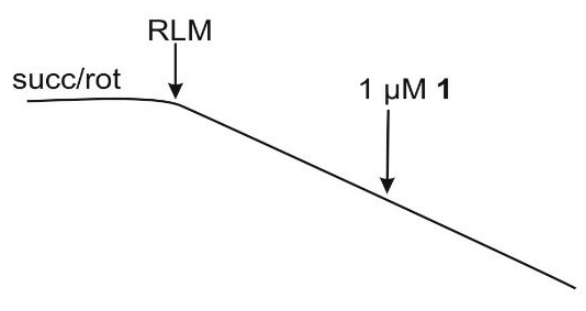

C

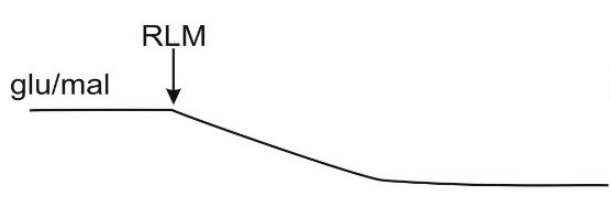

B

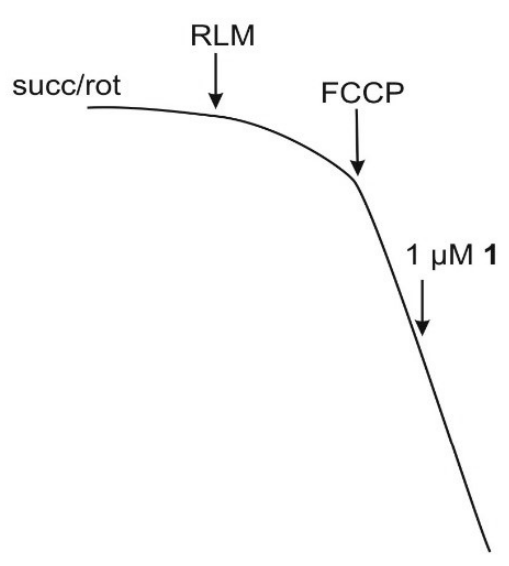

D

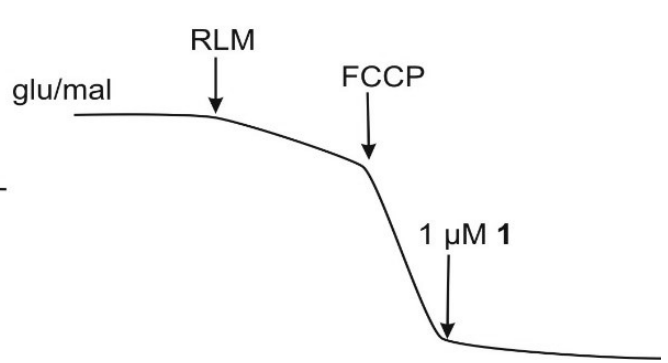

Figure 6. Effects of compound 1 on oxygen consumption in the absence or in the presence of the inhibitor of phosphorylation FCCP. (A,B): RLM $(1 \mathrm{mg} / \mathrm{mL})$ were incubated in a medium containing succ $(5 \mathrm{mM})$ and $\operatorname{rot}(1.25 \mu \mathrm{M})$. (C,D): RLM $(1 \mathrm{mg} / \mathrm{mL})$ were incubated in a medium containing glut $(5 \mathrm{mM})$ and $\mathrm{mal}(1 \mathrm{mM})$. Test compound was added at indicated concentration. FCCP concentration was $0.1 \mu \mathrm{g} / \mathrm{mg}$ protein.

\subsection{Mitochondrial Permeability Transition}

As it is well known, mitochondria incubated in energized conditions, and in the presence of high $\mathrm{Ca}^{2+}$ concentrations, undergo the so-called mitochondrial permeability transition (MPT) with the opening of the transition pore [42]. This event causes a bidirectional traffic of solutes and metabolites across the mitochondrial membranes leading to the collapse of the mitochondrial gradients, matrix swelling and the release of proapoptotic factors [43].

The induction of MPT is generally detected by measuring mitochondrial swelling. The results of Figure 7A show that RLM, energized by succ/rot and treated with $100 \mu \mathrm{M} \mathrm{Ca}^{2+}$, undergo a large amplitude swelling detected by a decrease in the apparent absorbance of mitochondrial suspension 
measured at $540 \mathrm{~nm}\left(+\mathrm{Ca}^{2+}\right)$. This event does not occur in the absence of $\mathrm{Ca}^{2+}\left(-\mathrm{Ca}^{2+}\right)$ or in the presence of the inhibitor of $\mathrm{Ca}^{2+}$ transport, ruthenium red (RR), thus evidencing the need of $\mathrm{Ca}^{2+}$ for inducing MPT. It is also evident that for inducing this phenomenon, $\mathrm{Ca}^{2+}$ has to enter into mitochondria by its electrophoretic uniport and consequently, the organelles have to be energized. This is confirmed by the results obtained with complex I inhibitor, ant A, that indeed completely prevents mitochondrial swelling. If 1 is added before $\mathrm{Ca}^{2+}$, at concentrations of $10 \mathrm{nM}$ or $1 \mu \mathrm{M}$, in the above condition (succ/rot), the mitochondrial swelling is not affected, suggesting that $\mathrm{Ca}^{2+}$ transport is normally operating in the presence of $\mathbf{1}$ (results not shown). It is also evidence that both $R R$ and ant A block swelling also in the presence of 1 .

A

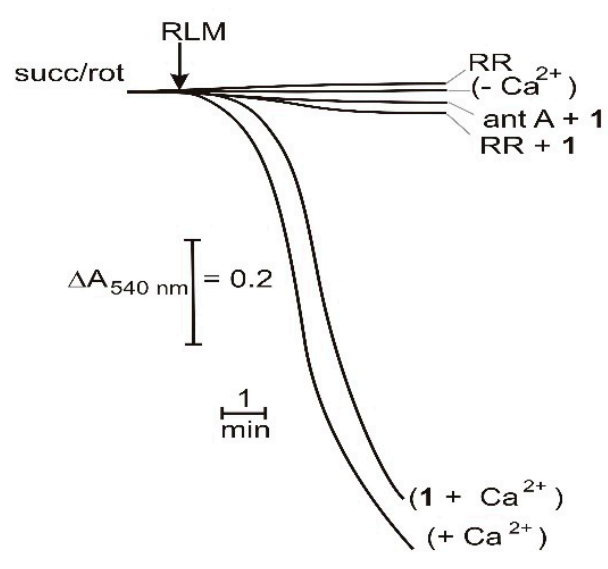

B

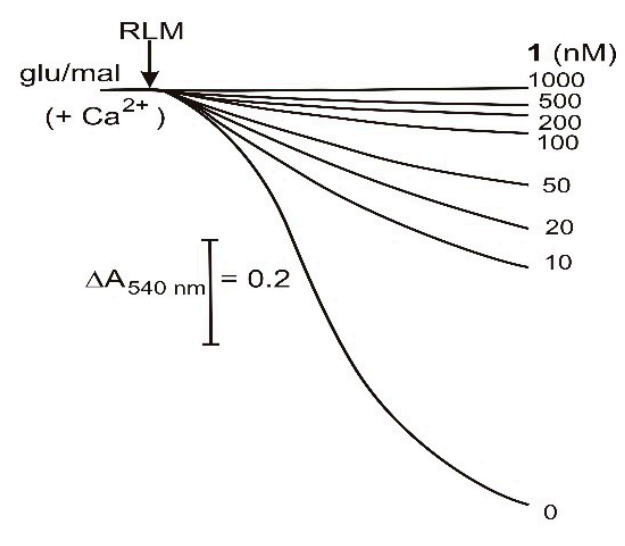

C

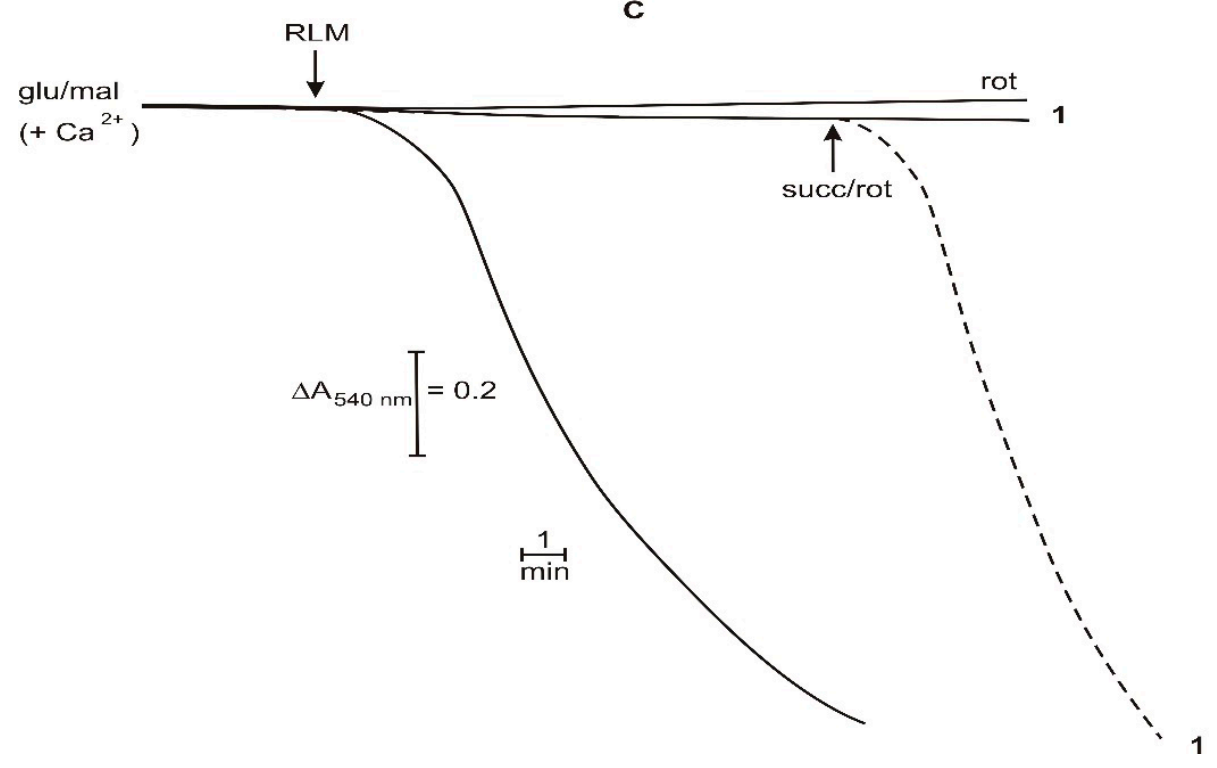

Figure 7. Effects of compound 1 on mitochondrial swelling. (A): RLM (1 mg/mL) were incubated in a medium containing succ $(5 \mathrm{mM})$ and $\operatorname{rot}(1.25 \mu \mathrm{M})$. (B,C): RLM $(1 \mathrm{mg} / \mathrm{mL})$ were incubated in a medium containing glu $(5 \mathrm{mM})$ and mal $(1 \mathrm{mM})$. Test compound was added at $1 \mu \mathrm{M}(\mathbf{A}, \mathbf{C})$ or at indicated concentrations (B). $\mathrm{Ca}^{2+}$ was present or added at $20 \mu \mathrm{M}$. Dotted line represents the behavior of mitochondrial swelling without the addition indicated by the arrow.

RLM energized by glu/mal and treated with $\mathrm{Ca}^{2+}$ also exhibit mitochondrial swelling without any significant change with respect to the above experimental conditions (Figure 7B). Nevertheless, if different concentrations of $\mathbf{1}$ are added, a dose-dependent inhibition of mitochondrial swelling occurs. 
Interestingly, both rot and compound 1 at $1 \mu \mathrm{M}$ concentration, completely inhibit the swelling of RLM energized by glu/mal (Figure 7C). Moreover, the inhibition of swelling exerted by $\mathbf{1}$ is completely removed by the addition of succ/rot, and this result demonstrates that rot and $\mathbf{1}$ exhibit an almost identical inhibitory effect. The restoration of the energizing condition by succ/rot addition, in turn, restores mitochondrial swelling (Figure 7C).

\subsection{Cytofluorimetric Analysis}

To prove the involvement of mitochondrial damage on the cell effects induced by annopurpuricin A (1), the mitochondrial functionality in the presence of test compound was evaluated in whole HeLa cells by using JC-1 (5, $5^{\prime}, 6,6^{\prime}$-tetrachloro-1,1',3,3'-tetraethylbenzimidazolocarbo-cyanine iodide). The high mitochondrial $\Delta \Psi$, negative inside, drives the uptake of this cationic probe into the matrix, leading to a highly red fluorescent emission. Following the collapse of mitochondrial $\Delta \Psi$, JC-1 leaks out from the organelles into the cytoplasm, resulting in a decrease of red fluorescence. The presence of $\mathbf{1}$ at $5 \mathrm{nM}$ concentration induces a significant decrease of red fluorescence in cells with mitochondria labeled with JC-1 (Figure 8A). In particular, the percentage of cells showing depolarized mitochondria rises from $7.7 \%$ in untreated cells (control) to $30.4 \%$ in cells treated with $\mathbf{1 .}$

A
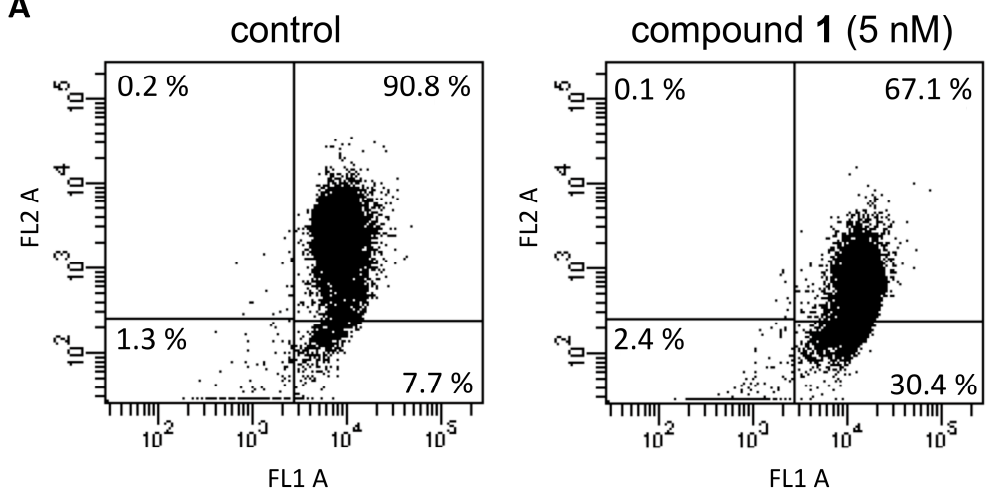

B

control
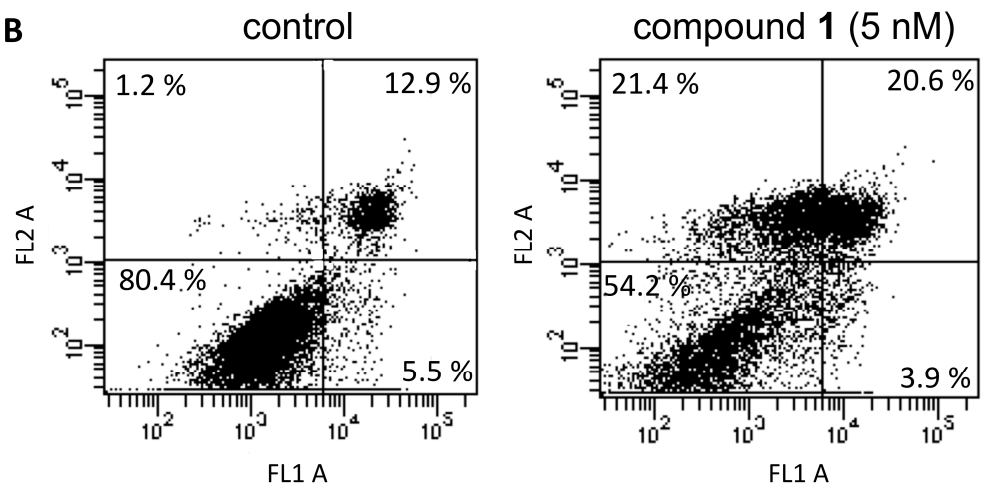

Figure 8. Effect of 1 on (A) mitochondrial $\Delta \Psi$ of cells stained with JC-1 or (B) cell death mechanism. Dot plots from the flow cytometry analysis performed on HeLa cells incubated for $28 \mathrm{~h}$ in the absence (control) or in the presence of $5 \mathrm{nM}$ compound 1. A representative experiment of at least three replicates is reported.

The result reporting that $\mathbf{1}$ is not able to induce MPT by preventing $\mathrm{Ca}^{2+}$ transport can be considered in the light of the triggering of intrinsic apoptosis at a cellular level. Nevertheless, if a block of the MPT induction can lead to a prevention of apoptosis, a block of complex I activity can result in a gradual deenergization of the cell, when the supply of $\mathrm{FADH}_{2}$ [flavin adenine dinucleotide (reduced form)] comes to lack, even though complex II should be operating, that can lead to cell death by necrosis. The investigation on the mechanism of cell death was performed by incubating HeLa cells in the presence of 1 at $5 \mathrm{nM}$ concentration for $28 \mathrm{~h}$. The obtained results highlighted a decrement of cell 
viability from $80.4 \%$ (untreated cells, control) to $54.2 \%$ in the presence of test compound (Figure $8 \mathrm{~B}$ ). Interestingly, annopurpuricin A (1) induces a significant increase of cells in late apoptosis (from 12.9\% to $20.6 \%$ ) and, more notably, an increase of necrotic cells from $1.2 \%$ to $21.4 \%$.

\section{Materials and Methods}

\subsection{General Experimental Procedures}

Melting points were obtained in a Fisher Johns fusiometer. Optical rotations were recorded in methanol on a JASCO P-2000 polarimeter. UV data were obtained on an Evolution 300 spectrophotometer in $\mathrm{MeOH}$ solution. Circular Dichroism spectra were performed on a JASCO 810 spectropolarimeter at $25^{\circ} \mathrm{C}$ in $\mathrm{MeOH}$ solution. FTIR spectroscopic data were measured on a Varian 660-IR spectrophotometer. NMR spectra were recorded in a Bruker $400 \mathrm{MHz}$ using $\mathrm{CDCl}_{3}$ and $\mathrm{C}_{6} \mathrm{D}_{6}$ as solvents. The chemical shifts are given in $\delta(\mathrm{ppm})$ and coupling constants $(J)$ are reported in Hz. ESI mass analysis was carried out employing a direct infusion in a triple quadrupole mass spectrometer Xevo TQD (Waters, Milford, MA, USA). The fragmentation patterns were obtained under conditions of capillary voltage: $2.5,3.0$ and $3.2 \mathrm{kV}$, cone voltage: 20,50 and $120 \mathrm{~V}$, collision energy: 10 to $35 \mathrm{~V}$; a source temperature of $300^{\circ} \mathrm{C}$, cone gas flow $40 \mathrm{~L} / \mathrm{h}$ and desolvation gas flow was adjusted to $600 \mathrm{~L} / \mathrm{h}$. The source parameters were established in positive ion mode $\left(\mathrm{ESI}^{+}\right)$with a sample flow of $10 \mu \mathrm{L} / \mathrm{min}$. The EI-MS analysis of trimethylsilyl derivatives was made in a Varian 3800 Gas Chromatograph equipment coupled with Varian Saturn 2200 Ion Trap Mass Spectrometer. The flow were set at $1 \mathrm{~mL} / \mathrm{min}$ with a temperature range from $100^{\circ} \mathrm{C}$ to $280^{\circ} \mathrm{C}$. High-resolution mass spectra were acquired with an Agilent Technologies ESI-TOF spectrometer. Additional elemental analyses were performed on a Truspec ${ }^{\circledR}$ Micro Analyzer. The purity of each isolate was determined by HPLC analysis performed on a Waters e2695 coupled with a photodiode array detection 2998, using an analytical column XBRIDGE (3.5 $\mu \mathrm{m}, 4.6 \times 150 \mathrm{~mm}, \mathrm{C}_{18}$ ), the mobile phase was $\mathrm{MeOH} /$ water (90:10), with a flow of $1 \mathrm{~mL} / \mathrm{min}$. The detector was set at $210 \mathrm{~nm}$. The diode array detector was set at 200-600 nm. The Empower 3 software program (Waters) performed control of the equipment, data acquisition, processing and management of chromatographic information.

\subsection{Plant Material}

The roots of Annona purpurea Moc \& Sessé ex Dunal were collected in January 2014, in Minatitlán, Colima, México, $\left(19^{\circ} 21^{\prime} 24.4^{\prime \prime} \mathrm{N}, 104^{\circ} 05^{\prime} 01.6^{\prime \prime}\right)$. The plant was correctly identified at the "Herbario Nacional de México" (MEXU) of the "Universidad Nacional Autónoma de México (UNAM)" and a voucher specimen was deposited (MEXU 1457308). An additional collection from Santa María, Michoacán, Mexico was also used (MEXU 1054418) to compare the presence of the metabolites in a different area (data not included). Considering the importance of the root in the survival of a tree, the sample taken by individual was an amount that did not represent risk, and after the collection a continuous monitoring of the survival of trees was made.

\subsection{Extraction and Isolation}

Roots of A. purpurea ( $3.47 \mathrm{Kg}$ ) were cleaned, dried and ground. Then, they were exhaustively extracted with hexane, DCM and methanol by maceration at room temperature $(24 \mathrm{~h} \times 5 \mathrm{~L})$ to give three extracts, hexane $(10.2 \mathrm{~g}), \mathrm{DCM}(20.1 \mathrm{~g})$ and methanol $(103.5 \mathrm{~g})$. The extracts were analyzed by TLC. Kedde's reagent was employed to detect the presence of lactones in the DCM extract. Separation of the compounds present in the DCM extract was carried out using a chromatographic column of $4 \Phi \times$ $60 \mathrm{~cm}$ packed with silica gel for thin layer chromatography (Macherey-Nagel). The column was loaded with $13 \mathrm{~g}$ of the extract, and it was eluted stepwise with solutions of n-hexane: ethyl acetate: methanol of increasing polarity. During the elution procedure, 210 fractions of $25 \mathrm{~mL}$ volume were obtained. The composition of the eluent solutions and their total volumes where: 100:0:0 (250 mL, fractions 1-10), 90:10:0 (500 mL, fractions 11-30), 80:20:0 (750 mL, fractions 31-60), 70:30:0 (750 mL, fractions 61-90), 
50:50:0 (1000 mL, fractions 91-130), 20:80:0 (750 mL, fractions 131-160), 0:100:0 (1400 mL, fractions 161-200), 0:80:20 (125 mL, fractions 201-205), 0:0:100 (125 mL, fractions 206-210). These fractions were grouped in 27 pools (A-Z) according to the TLC profile, of which the most abundant fractions were I (fractions 100-115), R (fractions 131-143), W (fractions (147-160), X (fractions 167-170), Z (172-202); showing a positive reaction to Kedde's reagent. These pools were purified to afford compounds 1 to 5 . Compound 1 (500 mg) was obtained from fraction $\mathrm{Z}$ by precipitation with a cold mixture of hexane: acetonitrile (1:1). 2 (30 mg) and $4(268 \mathrm{mg})$ were obtained by a similar method employing the fractions $\mathrm{W}$ and $\mathrm{X}$, respectively. Treatment of the fraction $\mathrm{R}$ with a heterogeneous system of methanol and hexane (95:5) yielded the purification of a white solid 3 (209 mg). Compound 5 was obtained from fraction I by treatment with methanol until a white wax was obtained; this was subsequently precipitated employing a mixture of hexane and acetonitrile (1:2) to yield $185.8 \mathrm{mg}$.

\subsubsection{Annopurpuricin A (1)}

Yellow amorphous powder; $0.018 \%(500 \mathrm{mg}) ; \mathrm{mp} 57-60^{\circ} \mathrm{C} ;[\alpha]^{25} \mathrm{D}+0.34^{\circ}(c 0.02, \mathrm{MeOH}) ; \mathrm{CD}$ $(\mathrm{MeOH}) \Delta \varepsilon(\mathrm{nm}):-2.09 \times 10^{3}$ (237.5); UV (MeOH) $\lambda \max (\log \varepsilon) 209$ (4.00); IR vmax 3369, 2916, 2850, $1742,1471,1324,1080$, and $869 \mathrm{~cm}^{-1}$; HRMS (ESI-TOF) $\mathrm{m} / z: 645.4695\left[\mathrm{C}_{37} \mathrm{H}_{66} \mathrm{O}_{7}+\mathrm{Na}\right]^{+}$, calcd. 645.4701 $\left[\mathrm{C}_{37} \mathrm{H}_{66} \mathrm{O}_{7} \mathrm{Na}\right]^{+}$, calcd. $622.4809\left[\mathrm{C}_{37} \mathrm{H}_{66} \mathrm{O}_{7}\right] .{ }^{1} \mathrm{H}$ and ${ }^{13} \mathrm{C}$ NMR spectroscopic data, see Table 1.

\subsubsection{Annopurpuricin B (2)}

White amorphous powder; $1.30 \times 10^{-3} \%(30 \mathrm{mg}) ; \mathrm{mp} 65-66^{\circ} \mathrm{C} ;[\alpha]^{25} \mathrm{D}-0.11^{\circ}(c 0.02, \mathrm{MeOH})$; $\mathrm{CD}(\mathrm{MeOH}) \Delta \varepsilon(\mathrm{nm}):-1.81 \times 10^{3}$ (237.5); UV (MeOH) $\lambda \max (\log \varepsilon) 212$ (4.00); IR vmax 3414, 3370, 2916, 2849, 1737, 1471, $1072 \mathrm{~cm}^{-1}$; HRMS (ESI-TOF) $\mathrm{m} / \mathrm{z}: 645.4700\left[\mathrm{C}_{37} \mathrm{H}_{66} \mathrm{O}_{7}+\mathrm{Na}\right]^{+}$, calcd. 645.4701 $\left[\mathrm{C}_{37} \mathrm{H}_{66} \mathrm{O}_{7} \mathrm{Na}\right]^{+}$, calcd. $622.4809\left[\mathrm{C}_{37} \mathrm{H}_{66} \mathrm{O}_{7}\right] .{ }^{1} \mathrm{H}$ and ${ }^{13} \mathrm{C}$ NMR spectroscopic data, see Table 1.

\subsubsection{Annopurpuricin C (3)}

White amorphous powder; $6.65 \times 10^{-3 \%}$ (209 mg); $\mathrm{mp} 69-71^{\circ} \mathrm{C} ;[\alpha]^{25} \mathrm{D}+0.44^{\circ}(c 0.02, \mathrm{MeOH})$; $\mathrm{CD}(\mathrm{MeOH}) \Delta \varepsilon(\mathrm{nm}):-2.16 \times 10^{3}$ (237.5); UV (MeOH) $\lambda \max (\log \varepsilon) 209$ (4.00); IR vmax 3414, 2915, 2849, 1743, 1471, $1070 \mathrm{~cm}^{-1}$; HRMS (ESI-TOF) $\mathrm{m} / z$ : $629.4753\left[\mathrm{C}_{37} \mathrm{H}_{66} \mathrm{O}_{6}+\mathrm{Na}\right]^{+}$, calcd. 629.4752 $\left[\mathrm{C}_{37} \mathrm{H}_{66} \mathrm{O}_{6} \mathrm{Na}\right]^{+}$, calcd. $606.4859\left[\mathrm{C}_{37} \mathrm{H}_{66} \mathrm{O}_{6}\right] .{ }^{1} \mathrm{H}$ and ${ }^{13} \mathrm{C}$ NMR spectroscopic data, see Table 2.

\subsubsection{Annopurpuricin D (4)}

White amorphous powder; $8.1 \times 10^{-3} \%(268 \mathrm{mg}) ; \operatorname{mp} 77-78^{\circ} \mathrm{C} ;[\alpha]^{25} \mathrm{D}-0.27^{\circ}(c 0.02, \mathrm{MeOH})$; $\mathrm{CD}(\mathrm{MeOH}) \Delta \varepsilon(\mathrm{nm}):-1.67 \times 10^{3}$ (238.5); UV (MeOH) $\lambda \max (\log \varepsilon) 210$ (3.94); IR vmax 3413, 2917, 2850, 1740, 1072 and $1025 \mathrm{~cm}^{-1}$; HRMS (ESI-TOF) m/z: $645.4706\left[\mathrm{C}_{37} \mathrm{H}_{66} \mathrm{O}_{7}+\mathrm{Na}\right]^{+}$, calcd. 645.4701 $\left[\mathrm{C}_{37} \mathrm{H}_{66} \mathrm{O}_{7} \mathrm{Na}\right]^{+}$, calcd. $622.4809\left[\mathrm{C}_{37} \mathrm{H}_{66} \mathrm{O}_{7}\right] .{ }^{1} \mathrm{H}$ and ${ }^{13} \mathrm{C}$ NMR spectroscopic data, see Table 2.

\subsubsection{Annopurpuricin E (5)}

White amorphous powder; $5.63 \times 10^{-3 \%}(185.8 \mathrm{mg}) ; \mathrm{mp} 55-56{ }^{\circ} \mathrm{C} ;[\alpha]^{25} \mathrm{D}-0.43^{\circ}(c 0.02, \mathrm{MeOH})$; $\mathrm{CD}(\mathrm{MeOH}) \Delta \varepsilon(\mathrm{nm}):-1.68 \times 10^{3}$ (239); UV (MeOH) $\lambda \max (\log \varepsilon) 208$ (3.85); IR vmax 2950, 2916, 2848, $1748,1462,831 \mathrm{~cm}^{-1}$; HRMS (ESI-TOF) $m / z: 595.4693\left[\mathrm{C}_{37} \mathrm{H}_{64} \mathrm{O}_{4}+\mathrm{Na}\right]^{+}$, calcd. $595.4697\left[\mathrm{C}_{37} \mathrm{H}_{64} \mathrm{O}_{4} \mathrm{Na}^{3+}\right.$, calcd. $572.4804\left[\mathrm{C}_{37} \mathrm{H}_{64} \mathrm{O}_{4}\right] \cdot{ }^{1} \mathrm{H}$ and ${ }^{13} \mathrm{C}$ NMR spectroscopic data, see Table 2.

\subsection{Preparation of Derivatives}

\subsubsection{Acetyl derivatives (1a-4a)}

Treatment of 1-4 (10 mg) with acetic anhydride/pyridine (room temperature, $18 \mathrm{~h}$ ) and subsequent work-up gave compounds 1a-4a (13-20 mg of yield) as a yellow semisolid [20]. 


\subsubsection{Trimethylsilyl Derivative}

A $1 \mathrm{mg}$ sample of each dry compound (1-4) was treated with N,O-Bis (trimethylsilyl) trifluoroacetamide (BSTFA) (Sigma Chemical Co., St. Louis, MO, USA) and dry pyridine (10: 1) at room temperature for $30 \mathrm{~min}$. The derivatization conditions were applied following the conditions given by the supplier with slight modifications to obtain the analytical response [44].

\subsection{3. $(R)$ - and (S)-MTPA Ester Derivatives}

In a $5 \mathrm{~mL}$ round-bottom flask, $5 \mathrm{mg}$ of the selected acetogenin (1-4) was dissolved in $1 \mathrm{~mL}$ of $\mathrm{CH}_{2} \mathrm{Cl}_{2}$, after that, $36 \mathrm{mg}$ of the (R)-(+)- $\alpha$-Methoxy- $\alpha$-trifluoromethylphenylacetic acid [(R)-MTPA] were added. The reaction was mixed with a magnetic stir bar and placed on ice bath, under a $\mathrm{N}_{2}$ gas flow. Subsequently, $30 \mathrm{mg}$ of DCC and $5 \mathrm{mg}$ of DMAP were added. The reaction system was carefully shaken in an ice bath for $5 \mathrm{~min}$, and then at room temperature. After that dicyclohexylurea precipitated. Each reaction was monitored by TLC and dried under vacuum pressure once the reaction had finished. Then, the residue was percolated using Si-gel and employing an ascending polarity system as eluent. Finally, the product was dissolved in $\mathrm{CDCl}_{3}$ and analyzed by ${ }^{1} \mathrm{H}$ NMR spectroscopy. The (S)-MTPA ester of each acetogenin was prepared from (S)-MTPA [(S)-(-)- $\alpha$-methoxy- $\alpha$-(trifluoromethyl)phenylacetic acid] following the same method [26]. All reactive were purchased by (Sigma Chemical Co., St. Louis, MO, USA).

\subsection{Computational Details}

Geometry optimizations of the acetogenins, without symmetry restrictions, were performed within the density functional theory framework implemented in the Gaussian 09 [45] code. The hybrid functional B3LYP [46] and wB97XD which uses a version of Grimme's D2 dispersion model [47], were employed together with the all-electron $6-311 G(d, p)$ basis set. The minimum energy states were verified through a vibrational analysis at the same theory level and compared with experimental FTIR data of each acetogenin. The harmonic frequencies were scaled depending on the function, namely, 0.9614 value for B3LYP functional as recommended by Scott and Random [48] and 0.957 value for the other functional as suggested by the Computational Chemistry Comparison and Benchmark DataBase [49].

\subsection{Inhibition Growth Assay}

MSTO-211H and HeLa were grown in RPMI 1640 (Sigma Chemical Co., St. Louis, MO, USA) supplemented with $2.4 \mathrm{~g} / \mathrm{L}$ HEPES (2-[4-(2-hydroxyethyl)piperazin-1-yl]ethanesulfonic acid), 0.11 g/L pyruvate sodium and Nutrient Mixture F-12 [HAM] (Sigma Chemical Co., St. Louis, MO USA), respectively. HepG2 were grown in Dulbecco's Modified Eagle's Medium (Sigma Chemical Co., St. Louis, MO, USA). 10\% Heat-inactivated fetal bovine serum (Invitrogen, Carlsbad, CA, USA), 100 U/mL penicillin, $100 \mu \mathrm{g} / \mathrm{mL}$ streptomycin, and $0.25 \mu \mathrm{g} / \mathrm{mL}$ amphotericin B (Sigma Chemical Co., St. Louis, MO, USA) were added to all media. The cells were cultured at $37^{\circ} \mathrm{C}$ in a moist atmosphere of $5 \%$ carbon dioxide in air. Cells $\left(3 \times 10^{4}\right)$ were seeded into each well of a 24 -well cell culture plate. After incubation for $24 \mathrm{~h}$, various concentrations of the test acetogenins were added. The cells were then incubated in standard conditions for a further $72 \mathrm{~h}$. A trypan blue assay was performed to determine cell viability.

\subsection{Mitochondrial Isolation and Standard Incubation Procedures}

Rat liver was homogenized in isolation medium (250 mM sucrose, $5 \mathrm{mM}$ HEPES, $0.5 \mathrm{mM}$ EDTA, $\mathrm{pH} 7.4)$ and subjected to centrifugation $(900 \times g)$ for $5 \mathrm{~min}$. The supernatant was centrifuged at $12,000 \times$ $g$ for $10 \mathrm{~min}$ to separate the crude mitochondrial pellets. The resulting pellets were suspended in isolation medium lacking EDTA [50]. Protein content was measured by the Biuret method with BSA as 
standard [51]. The isolation of the RLM was performed in accordance with the guiding principles in the care and use of animals and approved by the Italian Ministry of Health.

RLM $\left(1 \mathrm{mg}\right.$ protein $\left.\mathrm{mL}^{-1}\right)$ were incubated in a water-jacketed cell at $20^{\circ} \mathrm{C}$. The standard medium contained $200 \mathrm{mM}$ sucrose, $10 \mathrm{mM}$ HEPES (pH 7.4), and $1 \mathrm{mM}$ sodium phosphate. Variations and/or other additions are described in the specific experiments presented.

\subsection{Determination of Mitochondrial Functions}

The $\Delta \Psi$ was measured by assessing the distribution of the lipophilic cation tetraphenylphosphonium $\left(\mathrm{TPP}^{+}\right)$across the mitochondrial membrane with an ion-selective electrode specific for $\mathrm{TPP}^{+}$[52] with a calomel reference electrode (Radiometer K401). In this method, the electrode potential was linear with respect to the logarithm of the $\mathrm{TPP}^{+}$activity, with a slope of $58 \mathrm{mV}$, according to the Nernst equation and the law of mass conservation, and assuming an inner mitochondrial volume of $1.4 \mathrm{~L} / \mathrm{mg}$ protein, calculated from the distributions of $\left[{ }^{14} \mathrm{C}\right]$ sucrose and ${ }^{3} \mathrm{H}_{2} \mathrm{O}$ [53]. $\mathrm{TPP}^{+}$was added at a concentration of $2 \mu \mathrm{mol} \mathrm{L}^{-1}$ to allow accurate measurements while avoiding toxic effects on the $\mathrm{H}^{+}$-ATPase and $\mathrm{Ca}^{2+}$ [52-54]. $\Delta \Psi$ measured with the $\mathrm{TPP}^{+}$electrode was calibrated using the equation: $\Delta \Psi=(\Delta \Psi$ electrode-66.16 $) / 0.92$ [54]. The $\mathrm{RCI}$ was calculated by determining the difference in rates of oxygen uptake between respiratory state 4 (in the absence of $300 \mu \mathrm{mol} \mathrm{L}{ }^{-1} \mathrm{ADP}$ ) and state 3 (in the presence of $300 \mu \mathrm{mol} \mathrm{L}^{-1} \mathrm{ADP}$ ) using a Clark oxygen electrode (Yellow Springs Instrument Co. Inc., Yellow Springs, OH, USA) in a closed, thermostatically controlled vessel with a magnetic stirrer, coupled to a Perkin-Elmer 561 recorder [55]. The ADP/O ratio was calculated by dividing the concentration of added ADP by the corresponding oxygen uptake during respiratory state 3 .

\subsection{Determination of Mitochondrial Membrane Potential on Whole Cells}

The mitochondrial $\Delta \Psi$ was evaluated by using the BD $^{\mathrm{TM}}$ MitoScreen Kit (BD Biosciences, San Jose, USA) containing the membrane-permeable lipophilic cationic fluorochrome 5, $5^{\prime}, 6,6^{\prime}$-tetrachloro-1,1',3,3' 'tetraethylbenzimidazolcarbocyanine iodide (JC-1) [56]. HeLa cells (2.5 $\times$ $10^{5}$ ) were seeded into each cell culture plate. After $24 \mathrm{~h}$ of incubation, the test agent was added to the complete medium at the indicated concentration and cells were incubated for a further $28 \mathrm{~h}$. After treatment, cells were centrifuged, resuspended in JC-1 working solution and incubated for $30 \mathrm{~min}$ at $37^{\circ} \mathrm{C}$ in $\mathrm{CO}_{2}$ incubator. Following incubation, cells were washed twice, suspended in assay buffer and analyzed by a FACSCanto II flow cytometer. Results are presented as percentage of cells with depolarized mitochondrial membrane (JC-1 monomers) [56].

\subsection{Evaluation of Apoptotic Cell Death}

To detect phosphatidylserine translocation from the inner to the outer face of plasma membrane a FITC Annexin V Apoptosis Detection Kit I (BD Pharmingen, San Jose, USA) was used. HeLa cells $\left(2.5 \times 10^{5}\right)$ were seeded into each cell culture plate. After incubation for $24 \mathrm{~h}$ the test acetogenin was added to the complete medium at the indicated concentration and the cells were incubated for a further $28 \mathrm{~h}$. After treatment, the cells were centrifuged and suspended at $10^{6}$ cells $/ \mathrm{mL}$ in binding buffer. Cell suspensions $(100 \mu \mathrm{L})$ were added with Annexin V-FITC and propidium iodide (PI) as indicated by the supplier's instructions and incubated for $15 \mathrm{~min}$ at room temperature in the dark. The populations of Annexin V-negative/PI-negative (viable), Annexin V-positive/PI-negative (early apoptosis), Annexin V-positive/PI-positive (late apoptosis) and Annexin V-negative/PI-positive (necrosis) cells were evaluated by FACSCanto II flow cytometer (Becton-Dickinson, Mountain View, CA, USA) [57].

\section{Conclusions}

Although a previous study reports the presence of an alkaloid [21], our results demonstrated that bis-THF acetogenins are also present in the roots of A. purpurea, which is in total agreement with 
previous studies of its leaves and seeds $[16,19,20]$. Five new acetogenins, named annopurpuricins A-E (1-5), were isolated from roots of Annona purpurea. Their structures and absolute configuration were determined by interpretation of the spectroscopic data of original compounds and some of their derivatives. Compounds 1-4 showed a significant cytotoxic activity on MSTO-211H, HeLa and HepG2 cancer cell lines with $\mathrm{GI}_{50}$ values in the nanomolar range. In particular, annopurpuricin A (1) a bis-THF acetogenin, was the main component of the DCM extract $\left(0.018 \%\right.$ yield) and showed a $\mathrm{GI}_{50}$ value notably low on HeLa cells $(0.06 \mathrm{nM})$. The investigation on the mechanism of action of $\mathbf{1}$ highlighted the ability to inhibit NADH dehydrogenase (complex I) in RLM, similarly to rot. Cytofluorimetric experiments demonstrated that $\mathbf{1}$ is able to cause the depolarization of mitochondrial membrane in whole cells, and able to induce cell death through late apoptosis and necrosis.

Supplementary Materials: Supplementary Materials can be found at http://www.mdpi.com/1422-0067/20/8/1870/ s1.

Author Contributions: Investigation, G.A.H.-F. and A.N.G.-A.; Methodology, A.T.; Project administration, L.D.V. and H.P.-D.; Software, Z.G.-S. and J.P.M.-S.; Supervision, A.N.G.-A., A.L.P.C., I.D.-E., R.M.-V., F.J.M.-M., L.D.V. and H.P.-D.; Writing—original draft, G.A.H.-F.; Writing—review \& editing, L.D.V. and H.P.-D.

Funding: This work was supported by Italian Ministry of Education, University and Research (MIUR, Rome, Italy) H. Parra-Delgado thanks the financial support from PRODEP, CONACYT (0226165) and PROFOCIE 2014. G.A. Hernández-Fuentes thanks the financial support from CONACYT for his PhD studies (633738).

Acknowledgments: Authors express their gratitude to M.C. Rafael Torres Colin (Herbario Nacional de México, MEXU) for the identification of the species and to Rosa Santillán (CINVESTAV) for the HRMS acquisition. Also, the authors thank the help of Rigoberto López, Agustin Rosas and Juliana C. Palomo in the collection of the species.

Conflicts of Interest: The authors declare no conflict of interest.

\section{Abbreviations}

$\begin{array}{ll}\text { ADP } & \text { Adenosine diphosphate } \\ \text { ant A } & \text { Antimycin A } \\ \text { asc } & \text { Ascorbate } \\ \text { Bis-THF } & \text { Bis tetrahydrofuran } \\ \text { BSTFA } & \text { N,O-Bis(trimethylsilyl)trifluoroacetamide } \\ \text { B3LYP } & \text { Becke, three-parameter, Lee-Yang-Parr } \\ \text { OTMSi } & \text { O-trimethylsilyl ether } \\ \text { CD } & \text { Circular dichroism } \\ \text { C }_{6} \text { D }_{6} & \text { Benzene- } d_{6} \\ \text { COSY } & \text { Correlated spectroscopy } \\ \text { DCM } & \text { Dichloromethane } \\ \text { ESI-TOF } & \text { Electrospray ionization time-of-flight mass spectrometry } \\ \text { FADH } 2 & \text { flavin adenine dinucleotide (reduced form) } \\ \text { FCCP } & \text { Carbonyl cyanide-4-(trifluoromethoxy)phenylhydrazone } \\ \text { FITC } & \text { Fluorescein isotiocyanate } \\ \text { FTIR } & \text { Fourier transform infrared spectroscopy } \\ \text { glu } & \text { Glutamate } \\ \text { HEPES } & \text { 2-[4-(2-hydroxyethyl)piperazin-1-yl]ethanesulfonic acid } \\ \text { HMBC } & \text { Heteronuclear multiple bond correlation } \\ \text { HRMS } & \text { High-resolution mass spectra } \\ \text { HSQC } & \text { Heteronuclear single-quantum correlation } \\ \text { Hz } & \text { Hertz } \\ \text { JC-1 } & 5,5^{\prime}, 6,6^{\prime} \text {-tetrachloro-1, } 1^{\prime}, 3,3^{\prime} \text {-tetraethylbenzimidazolocarbo-cyanine iodide } \\ \text { mal } & \text { Malate }\end{array}$




$\begin{array}{ll}\text { mp } & \text { Melting point } \\ \text { MPT } & \text { Mitochondrial permeability transition } \\ \text { NADH } & \text { Nicotinamide adenine dinucleotide reduced form } \\ { }^{1} \mathrm{H} \text { NMR } & \text { Proton nuclear magnetic resonance } \\ { }^{13} \text { C NMR } & \text { Carbon-13 nuclear magnetic resonance } \\ \text { S-MTPA } & (\text { S)-(-)- } \alpha \text {-methoxy- } \alpha \text {-(trifluoromethyl)phenylacetic acid } \\ \text { ppm } & \text { Parts per million } \\ \text { RCI } & \text { Respiration control index } \\ \text { rot } & \text { Rotenone } \\ \text { R-MTPA } & (\text { R)-(-)- } \alpha \text {-methoxy- } \alpha \text {-(trifluoromethyl)phenylacetic acid } \\ \text { RLM } & \text { Rat liver mitochondria } \\ \text { RR } & \text { Ruthenium red } \\ \text { succ } & \text { Succinate } \\ \text { THF } & \text { Tetrahydrofuran } \\ \text { TMPD } & \text { N,N, }{ }^{\prime} \text {, } N^{\prime} \text {-tetramethyl-p-phenylenediamine } \\ \text { TPP+ } & \text { tetraphenylphosphonium cation } \\ \text { TMSi } & \text { Trimethylsilyl } \\ \text { UV } & \text { Ultraviolet-visible spectrophotometry } \\ \Delta \Psi & \text { Membrane potential }\end{array}$

\section{References}

1. Bories, C.; Loiseau, P.; Cortes, D.; Myint, S.; Hocquemiller, R.; Gayral, P.; Cavé, A.; Laurens, A. Antiparasitic activity of Annona muricata and Annona cherimolia seeds. Planta Med. 1991, 57, 434-436. [CrossRef] [PubMed]

2. Bourne, R.K.; Egbe, P.C. A preliminary study of the sedative effects of Annona muricata (sour sop). West Indian Med. J. 1979, 28, 106-110. [PubMed]

3. Cronquist, A. An Integrated System of Classification of Flowering Plants; Columbia University Press: New York, NY, USA, 1981; ISBN 0-231-03880-1.

4. Hasrat, J.A.; Pieters, L.; De Backer, J.-P.; Vauquelin, G.; Vlietinck, A.J. Screening of medicinal plants from Suriname for 5-HT1A ligands: Bioactive isoquinoline alkaloids from the fruit of Annona muricata. Phytomedicine 1997, 4, 133-140. [CrossRef]

5. Martínez, M. Las Plantas Medicinales de México, 6th ed.; Ediciones Botas: México, D.F., Mexico, 1989; ISBN 968-6334-07-6.

6. Emanuel, R.V. Árboles de Minatitlán, Colima: Guía de usos tradicionales, 1st ed.; PACMYC: Colima, México, 2016; Volume 1.

7. Zafra-Polo, M.C.; González, M.C.; Estornell, E.; Sahpaz, S.; Cortes, D. Acetogenins from annonaceae, inhibitors of mitochondrial complex I. Phytochemistry 1996, 42, 253-271. [CrossRef]

8. Zafra-Polo, M.C.; Figadère, B.; Gallardo, T.; Tormo, J.; Cortes, D. Natural acetogenins from annonaceae, synthesis and mechanisms of action. Phytochemistry 1998, 48, 1087-1117. [CrossRef]

9. Melot, A.; Fall, D.; Gleye, C.; Champy, P. Apolar annonaceous acetogenins from the fruit pulp of Annona muricata. Molecules 2009, 14, 4387-4395. [CrossRef] [PubMed]

10. Mangal, M.; Khan, M.I.; Agarwal, S.M. Acetogenins as potential anticancer agents. Anticancer Agents Med. Chem. 2015, 16, 138-159. [CrossRef]

11. Oberlies, N.H.; Chang, C.; McLaughlin, J.L. Structure-Activity relationships of diverse annonaceous acetogenins against multidrug resistant human mammary adenocarcinoma (MCF-7/Adr) Cells. J. Med. Chem. 1997, 40, 2102-2106. [CrossRef]

12. Wu, T.-Y.; Yang, I.-H.; Tsai, Y.-T.; Wang, J.-Y.; Shiurba, R.; Hsieh, T.-J.; Chang, F.-R.; Chang, W.-C. Isodesacetyluvaricin, an annonaceous acetogenin, specifically inhibits gene expression of cyclooxygenase-2. J. Nat. Prod. 2012, 75, 572-576. [CrossRef]

13. Kojima, N.; Fushimi, T.; Tatsukawa, T.; Tanaka, T.; Okamura, M.; Akatsuka, A.; Yamori, T.; Dan, S.; Iwasaki, H.; Yamashita, M. Thiophene-3-carboxamide analogue of annonaceous acetogenins as antitumor drug lead. Eur. J. Med. Chem. 2014, 86, 684-689. [CrossRef] 
14. Miyoshi, H.; Ohshima, M.; Shimada, H.; Akagi, T.; Iwamura, H.; McLaughlin, J.L. Essential structural factors of annonaceous acetogenins as potent inhibitors of mitochondrial complex I. Biochim. Biophys. Acta BBA-Bioenerg. 1998, 1365, 443-452. [CrossRef]

15. Nakanishi, S.; Abe, M.; Yamamoto, S.; Murai, M.; Miyoshi, H. Bis-THF motif of acetogenin binds to the third matrix-side loop of ND1 subunit in mitochondrial NADH-ubiquinone oxidoreductase. Biochim. Biophys. Acta BBA-Bioenerg. 2011, 1807, 1170-1176. [CrossRef] [PubMed]

16. Cepleanu, F.; Ohtani, K.; Hamburger, M.; Hostettmann, K.; Gupta, M.P.; Solis, P. Novel acetogenins from the leaves of Annona purpurea. Helv. Chim. Acta 1993, 76, 1379-1388. [CrossRef]

17. Chang, F.R.; Chen, C.Y.; Wu, P.H.; Kuo, R.Y.; Chang, Y.C.; Wu, Y.C. New alkaloids from Annona purpurea. J. Nat. Prod. 2000, 63, 746-748. [CrossRef] [PubMed]

18. Chang, F.-R.; Wei, J.-L.; Teng, C.-M.; Wu, Y.-C. Antiplatelet aggregation constituents from Annona purpurea. J. Nat. Prod. 1998, 61, 1457-1461. [CrossRef] [PubMed]

19. Chávez, D.; Mata, R. Purpuracenin: A new cytotoxic adjacent bis-tetrahydrofuran annonaceous acetogenin from the seeds of Annona purpurea. Phytochemistry 1999, 50, 823-828. [CrossRef]

20. Chávez, D.; Mata, R. Purpurediolin and purpurenin, two new cytotoxic adjacent bis-tetrahydrofuran annonaceous acetogenins from the seeds of Annona purpurea. J. Nat. Prod. 1998, 61, 580-584. [CrossRef]

21. Rejón-Orantes, J.D.C.; González-Esquinca, A.R.; de la Mora, M.P.; Roldan Roldan, G.; Cortes, D. Annomontine, an alkaloid isolated from Annona purpurea, has anxiolytic-like effects in the elevated plus-maze. Planta Med. 2011, 77, 322-327. [CrossRef]

22. Alali, F.Q.; Zhang, Y.; Rogers, L.; McLaughlin, J.L. Mono-tetrahydrofuran acetogenins from Goniothalamus giganteus. Phytochemistry 1998, 49, 761-768. [CrossRef]

23. Gawroński, J.; Wu, Y.-C. A note on the determination of absolute configuration of acetogenins by circular dichroism. Pol. J. Chem. 1999, 73, 241-243.

24. Cortes, D.; Figadere, B.; Cavé, A. Bis-tetrahydrofuran acetogenins from annonaceae. Phytochemistry 1993, 32, 1467-1473. [CrossRef]

25. Duret, P.; Waechter, A.-I.; Figadère, B.; Hocquemiller, R.; Cavé, A. Determination of absolute configurations of carbinols of annonaceous acetogenins with 2-naphthylmethoxyacetic acid esters. J. Org. Chem. 1998, 63, 4717-4720. [CrossRef]

26. Rieser, M.J.; Hui, Y.H.; Rupprecht, J.K.; Kozlowski, J.F.; Wood, K.V.; McLaughlin, J.L.; Hanson, P.R.; Zhuang, Z.; Hoye, T.R. Determination of absolute configuration of stereogenic carbinol centers in annonaceous acetogenins by proton and fluorine 19-NMR analysis of Mosher ester derivatives. J. Am. Chem. Soc. 1992, 114, 10203-10213. [CrossRef]

27. Gallardo, T.; Saez, J.; Granados, H.; Tormo, J.R.; Velez, I.D.; Brun, N.; Torres, B.; Cortes, D. 10-Oximeguanacone, the first nitrogenated acetogenin derivative found to be a potent inhibitor of mitochondrial complex I. J. Nat. Prod. 1998, 61, 1001-1005. [CrossRef]

28. Gu, Z.; Zhou, D.; Lewis, N.J.; Wu, J.; Shi, G.; McLaughlin, J.L. Isolation of new bioactive annonaceous acetogenins from Rollinia mucosa guided by liquid chromatography/mass spectrometry. Bioorg. Med. Chem. 1997, 5, 1911-1916. [CrossRef]

29. Liu, X.-X.; Alali, F.Q.; Hopp, D.C.; Rogers, L.L.; Pilarinou, E.; McLaughlin, J.L. Glabracins A and B, two new acetogenins from Annona glabra. Bioorg. Med. Chem. 1998, 6, 959-965. [CrossRef]

30. Navrátilová, H.; de Gelder, R.; Křiž Z. Enantiodiscrimination in NMR Spectra and X-Ray Structures of Diastereomeric Salts of Trans-4-(4-Fluorophenyl)-3-Hydroxymethyl-1-Methylpiperidine with (S)-Mosher Acid. J. Chem. Soc. Perkin Trans. 2002, 2, 2093-2099. [CrossRef]

31. Zhao, G.-X.; Gu, Z.-M.; Zeng, L.; Chao, J.-F.; Kozlowski, J.F.; Wood, K.V.; McLaughlin, J.L. The absolute configuration of trilobacin and trilobin, a novel highly potent acetogenin from the stem bark of Asimina triloba (Annonaceae). Tetrahedron 1995, 51, 7149-7160. [CrossRef]

32. Raynaud, S.; Fourneau, C.; Hocquemiller, R.; Sévenet, T.; Hadi, H.A.; Cavé, A. Acetogenins from the bark of Uvaria pauci-ovulata. Phytochemistry 1997, 46, 321-326. [CrossRef]

33. Alali, F.Q.; Liu, X.-X.; McLaughlin, J.L. Annonaceous acetogenins: Recent progress. J. Nat. Prod. 1999, 62, 504-540. [CrossRef]

34. Chih, H.-W.; Chiu, H.-F.; Tang, K.-S.; Chang, F.-R.; Wu, Y.-C. Bullatacin, a potent antitumor annonaceous acetogenin, inhibits proliferation of human hepatocarcinoma cell line 2.2.15 by apoptosis induction. Life Sci. 2001, 69, 1321-1331. [CrossRef] 
35. Chen, Y.-Y.; Chang, F.-R.; Yen, H.-F.; Wu, Y.-C. Epomusenins A and B, two acetogenins from fruits of Rollinia mucosa. Phytochemistry 1996, 42, 1081-1083. [CrossRef]

36. Gleye, C.; Laurens, A.; Hocquemiller, R.; Laprévote, O.; Serani, L.; Cavé, A. Cohibins A and B, acetogenins from roots of Annona muricata. Phytochemistry 1997, 44, 1541-1545. [CrossRef]

37. Meneses da Silva, E.L.; Roblot, F.; Mahuteau, J.; Cavé, A. Coriadienin, the First Annonaceous Acetogenin with two double bonds isolated from Annona coriaceae. J. Nat. Prod. 1996, 59, 528-530. [CrossRef]

38. Tormo, J.R.; Zafra-Polo, M.C.; Serrano, A.; Estornell, E.; Cortes, D. Epoxy-acetogenins and other polyketide epoxy derivatives as inhibitors of the mitochondrial respiratory chain complex I. Planta Med. 2000, 66, 318-323. [CrossRef]

39. Vázquez-Vuelvas, O.F.; Hernández-Madrigal, J.V.; Gaviño, R.; Tlenkopatchev, M.A.; Morales-Morales, D.; Germán-Acacio, J.M.; Gomez-Sandoval, Z.; Garcias-Morales, C.; Ariza-Castolo, A.; Pineda-Contreras, A. X-ray, DFT, FTIR and NMR structural study of 2, 3-dihydro-2-(R-phenylacylidene)-1, 3, 3-trimethyl-1H-indole. J. Mol. Struc. 2011, 987, 106-118. [CrossRef]

40. Mazza, A.; Beccalli, E.M.; Contini, A.; Garcia-Argaez, A.N.; Dalla Via, L.; Gelmi, M.L. A new scaffold of topoisomerase I inhibitors: Design, synthesis and biological evaluation. Eur. J. Med. Chem. 2016, 124, 326-339. [CrossRef]

41. Afonso, S.; Silva, F.B.; Silva, A.F.; Scarminio, I.S.; Bruns, R.E. Infrared spectral evidence and DFT calculations of hydrogen-bonding and molecular structures of acetogenins. J. Mol. Struct. 2017, 1130, 174-180. [CrossRef]

42. Zoratti, M.; Szabò, I. The mitochondrial permeability transition. Biochim. Biophys. Acta 1995, 1241, $139-176$. [CrossRef]

43. Susin, S.A.; Lorenzo, H.K.; Zamzami, N.; Marzo, I.; Snow, B.E.; Brothers, G.M.; Mangion, J.; Jacotot, E.; Costantini, P.; Loeffler, M.; et al. Molecular characterization of mitochondrial apoptosis-inducing factor. Nature 1999, 397, 441-446. [CrossRef]

44. Schummer, C.; Delhomme, O.; Appenzeller, B.M.R.; Wennig, R.; Millet, M. Comparison of MTBSTFA and BSTFA in derivatization reactions of polar compounds prior to GC/MS analysis. Talanta 2009, 77, 1473-1482. [CrossRef]

45. Frisch, M.J.; Trucks, G.W.; Schlegel, H.B.; Scuseria, G.E.; Robb, M.A.; Cheeseman, J.R.; Scalmani, G.; Barone, V.; Petersson, G.A.; Nakatsuji, H.; et al. Gaussian 09, Revision A.02; Gaussian, Inc.: Wallingford, CT, USA, 2009.

46. Becke, A.D. Density-functional thermochemistry. III. The role of exact exchange. J. Chem. Phys. 1993, 98, 5648-5652. [CrossRef]

47. Chai, J.D.; Head-Gordon, M. Long-range corrected hybrid density functionals with damped atom-atom dispersion corrections. Phys. Chem. Chem. Phys. 2008, 10, 6615-6620. [CrossRef]

48. Scott, A.P.; Radom, L. Harmonic vibrational frequencies: An evaluation of Hartree-Fock, Møller-Plesset, quadratic configuration interaction, density functional theory, and semiempirical scale factors. J. Phys. Chem. 1996, 100, 16502-16513. [CrossRef]

49. NIST, N. Computational chemistry comparison and benchmark database. In NIST Standard Reference Database Number 101; NIST: Gaithersburg, MD, USA, 2010.

50. Schneider, W.C.; Hogeboom, G.H. Cytochemical studies of mammalian tissues; the isolation of cell components by differential centrifugation: A review. Cancer Res. 1951, 11, 1-22.

51. Gornall, A.G.; Bardawill, C.J.; David, M.M. Determination of serum proteins by means of the biuret reaction. J. Biol. Chem. 1949, 177, 751-766.

52. Kamo, N.; Muratsugu, M.; Hongoh, R.; Kobatake, Y. Membrane potential of mitochondria measured with an electrode sensitive to tetraphenyl phosphonium and relationship between proton electrochemical potential and phosphorylation potential in steady state. J. Membr. Biol. 1979, 49, 105-121. [CrossRef]

53. Palmieri, F.; Klingenberg, M. Direct methods for measuring metabolite transport and distribution in mitochondria. In Biomembranes Part G: Bioenergetics: Biogenesis of Mitochondria, Organization, and Transport; Methods, E., Fleisher, S., Packer, L., Eds.; Academic Press: Cambridge, MA, USA, 1979; Volume 56, pp. 279-301.

54. Gunter, T.E.; Jensen, B.D. The efficiencies of the component steps of oxidative phosphorylation. I. A simple steady state theory. Arch. Biochem. Biophys. 1986, 248, 289-304. [CrossRef]

55. Estabrook, R.W. Mitochondrial respiratory control and the polarographic measurement of ADP: O ratios. In Oxidation and Phosphorylation; Methods, E., Estabrook, R.W., Pullman, M.E., Eds.; Academic Press: Cambridge, MA, USA, 1967; Volume 10, pp. 41-47. 
56. Cossarizza, A.; Baccaranicontri, M.; Kalashnikova, G.; Franceschi, C. A new method for the cytofluorometric analysis of mitochondrial membrane potential using the J-aggregate forming lipophilic cation 5,5',6,6'-Tetrachloro-1,1',3,3'-tetraethylbenzimidazolcarbocyanine iodide (JC-1). Biochem. Biophys. Res. Commun. 1993, 197, 40-45. [CrossRef]

57. Van Engeland, M.; Nieland, L.J.; Ramaekers, F.C.; Schutte, B.; Reutelingsperger, C.P. Annexin V-affinity assay: A review on an apoptosis detection system based on phosphatidylserine exposure. Cytometry 1998, 31, 1-9. [CrossRef]

(C) 2019 by the authors. Licensee MDPI, Basel, Switzerland. This article is an open access article distributed under the terms and conditions of the Creative Commons Attribution (CC BY) license (http://creativecommons.org/licenses/by/4.0/). 